\title{
Tectônica e Água Subterrânea em Rochas Pré-Cambrianas do Nordeste do Brasil - A Diversidade do Sistema Aqüífero
}

\author{
Benjamim Bley de Brito Neves' (bbleybn@usp.br) e José do Patrocínio Tomaz Albuquerque² \\ 'Departamento de Mineralogia e Geotectônica - Instituto de Geociências - USP \\ R. do Lago 562, CEP 05508-080, São Paulo, SP, BRA \\ ${ }^{2}$ Departamento de Engenharia Civil - Centro de Ciências e Tecnologia - UFPB, Campina Grande, PB, BRA
}

Palavras-chave: sistema aquífero cristalino, semi-árido, Província Borborema, geotectônica, locação de poços, vazão específica.

\section{RESUMO}

Água subterrânea em rochas cristalinas fraturadas desempenha um importante papel no suprimento das províncias estruturais mais orientais (Borborema, ao norte; São Francisco, ao sul) do escudo brasileiro (Atlântico), grande parte delas estando situadas sob condições climáticas do semi-árido. Cerca de 100.000 poços foram perfurados em diferentes partes desta região de cerca de $1.000 .000 \mathrm{~km}^{2}$ nos últimos 150 anos. Apenas, critérios técnicos de locação de poços, baseados em geologia estrutural, começaram a ser introduzidos, tendo estes critérios experimentado algum progresso gradual (menos do que esperado) nos últimos 40 anos. Nestes termos, na medida que algum progresso foi registrado na locação dos poços, o número de poços secos e abandonados tem decrescido notoriamente. Além disso, há muitas possibilidades novas de pesquisas (geológicas e geofísicas) abertas para o futuro. Para os sistemas aqüíferos de rochas ígneas e metamórficas, um contexto de grande diversidade de problemas deve ser reconhecido primeiro de que tudo. Apesar da maioria dos textos (livros e publicações) serem caracterizados por um simplismo hidrogeológico, ora inaceitável. Esta grande diversidade é comandada por dois diferentes grupos de variáveis: os da Geotectônica (produto da dinâmica interna) e os das condições climáticas e fisiográficas (produtos da dinâmica externa). Estas condições conduzem à definição das melhores características gerais para locação do poço que deve ser perfurado. Um terceiro grupo de variáveis pode ser visualizada no "projeto de poço", o qual, para assegurar um desempenho adequado, o poço precisa ser corretamente construído, operado, mantido e usado (produtos da intervenção do homem/técnico). O exercício para determinar a proporção da influência de cada uma destas variáveis é difícil e discutível. Há alguns casos particulares onde, apenas, um grupo de fatores/variáveis é absolutamente preponderante no resultado final (capacidade específica e qualidade química) do poço. Baseado nos tipos crustais e na regionalização geotectônica desta parte do escudo, sete diferentes contextos do sistema aqüífero cristalino serão aqui discutidos e propostos.

Keywords: crystalline aquifer system, semiarid, Borborema Province, Tectonics, well site location, specific yield.

\section{ABSTRACT}

Groundwater in fractured crystalline rocks plays an important role in terms of water supply systems of the eastern structural provinces (Borborema to the north, São Francisco to the south) of the Brazilian Shield, the greater part of which under semi-arid climatic conditions. About 100,000 water wells have been drilled in different parts of this region of about $1,000,000 \mathrm{~km}^{2}$, over the last 150 years. Only during the last 40 years have technical criteria of location based on structural geology been used, and these criteria have gradually been improved, though less than it was wished. As progress was obtained in the location of wells in crystalline aquifers, so the number of dry or/and abandoned wells have decreased. There are many open possibilities for geological and geophysical research to be developed for the future. It is necessary to recognize that a very wide range of problems exists in the case of aquifer systems in igneous and metamorphic rocks. In spite of this, most texts on this subject (books and papers) are characterized by a simplism that is no longer acceptable. Such diversity is firstly determined by two different groups of variables, those associated with internal dynamics (domains of geotectonics), and those associated with external dynamics (climate and physiography). A third group of variable may be identified in the 
general water well characteristics, such as its location (well site) and well-design (engineering features), and its maintenance and use (anthropic factors). To establish the relative influences of these groups of variables is difficult and it is matter of dispute. There are some particular cases where only one group of factors/variables is absolutely preponderant in determining the final performance of the well (in terms of specific capacity and water quality). Regarding the crustal types and geotectonic regionalization of this part of the Brazilian (Atlantic) Shield, seven different types of conditions for the aquifer systems are proposed and discussed.

\section{INTRODUÇÃO}

Durante dezenas de anos os autores militaram na perfuração de poços para água subterrânea (inicialmente, como geólogos da SUDENE - Superintendência do Desenvolvimento do Nordeste), em diferentes partes do Nordeste Oriental (Figura 1) do Polígono das Secas. Em cada região/ área, onde escalado para trabalhar, havia nuances próprias e diferenças substanciais para a determinação da locação ideal. Em outras palavras, o aprendizado de uma região e os textos disponíveis na literatura (muito poucos nos anos 60) eram valiosos, mas não aplicáveis totalmente quando defrontados com outra região. Esta busca do entendimento da diversidade do sistema aqüífero, dentro de, praticamente, uma mesma região geológica natural, que se apresentava muito distante das preocupações da literatura especializada (tudo era tratado de forma genérica e simplista) motivou gradativamente os autores para uma guinada na pesquisa,

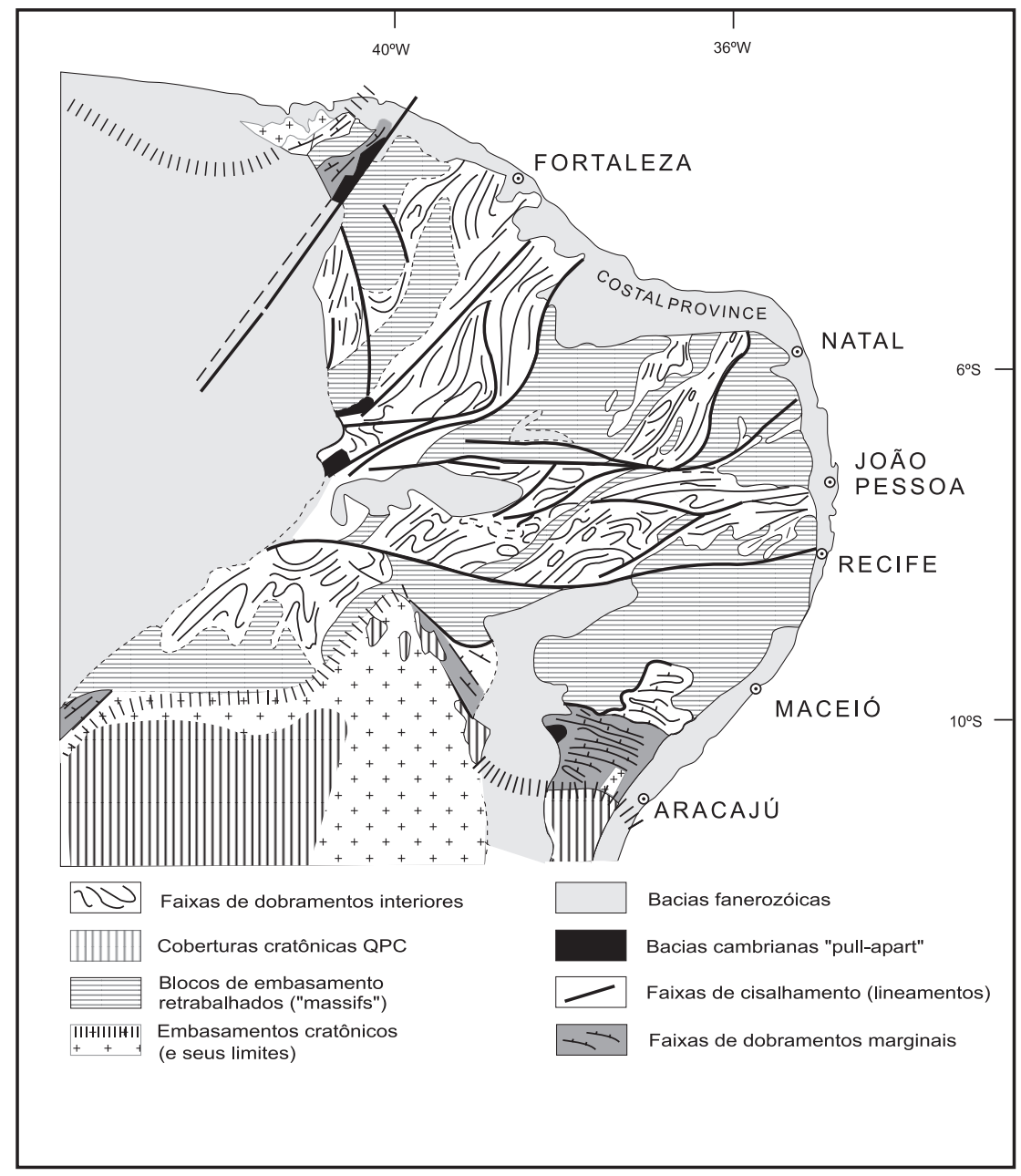

Figura 1. Esboço tectônico-geológico da Província Borborema, Nordeste do Brasil, com indicação dos diferentes elementos influentes no Sistema Aqüífero Cristalino. 
adentrando o campo da Regionalização Geotectônica.

Já na década de 60 , começou a se formar o consenso em torno da importância do fator clima, tanto na qualidade quanto na produção dos poços, o que não era prognosticado em nenhum texto da literatura disponível. Desta constatação, e dos dados acumulados na Província Borborema e áreas adjacentes (Figuras 2 e 3) há excelente registro do aspecto qualitativo, no trabalho pioneiro de Cruz e Mello (1968, Figura 4), seguido de vários outros (muitos deles sumulados na série de publicações do Inventário Hidrogeológico Básico do Nordeste da SUDENE, nas décadas de 60 e 70). Se em décadas passadas, o fator rocha era a principal preocupação, a partir deste trabalho pioneiro se consignou a importância e, até mesmo, a supremacia do fator clima na produção dos poços e qualidade de suas águas. Em resumo, ficou reconhecido que uma mesma litologia pode apresentar poços absolutamente diferentes em termos de qualidade e quantidade, de uma região climática a outra, e vários exemplos disso foram constatados, entre a faixa costeira ("zona da mata") e o alto sertão (semi-árido drástico). A preocupação prioritária (exagerada) com assembléias litológicas ou com determinadas litologias ditas "favoráveis" foi uma marca particular das pesquisas de água subterrânea do passado (décadas de 60 e 70).

Por outro lado, a noção das conexões entre morfologia e as águas subterrâneas foi um conhecimento que foi gradativamente se cristalizando e, com isto o manuseio correto do fator relevo (procura das áreas mais rebaixadas, talvegues, baixadas) passou a ser importante. Neste sentido, a preocupação com linhas de talvegue comandadas por fraturamento ("riachos-fendas") foi instaurada nos primórdios dos anos 60, com o clássico trabalho de Siqueira (1963).

No tocante à geotectônica, inclusive à sua disciplina morfológica (geologia estrutural), foi grande o desenvolvimento ensejado pela Análise da Deformação e da Neotectônica, que nos últimos 30 anos desencadearam uma revolução no Brasil e, particularmente na sua região Nordeste. A pesquisa de água subterrânea no Sistema Cristalino se beneficiou muito pouco, e apenas localmente (bem menos do que teria sido possível), destes ganhos incontestes (vide Silva et al., 2000a, 2000b; Albuquerque, 2003).

Em muitos campos houve progresso notável, como por exemplo, na caracterização da produção dos poços (método de capacidade específica fractal, de Manoel Filho, 1996). Mas, em termos de análise dos parâmetros tectônicos foi feito muito pouco. O problema permaneceu latente. Nas considerações de Manoel Filho (1996), baseado em Mandelbrot (1983), para a dimensão fractal dos meios fissurais, fica muito claro que faltou o condimento da geotectônica. E aquela preocupação, nascida nos anos 60 (dissertada no primeiro parágrafo), sobre a diversidade das condições de acordo com a geologia regional (quadro geotectônico) que era latente foi despertada.

Em 1997, uma primeira tentativa de abordar o problema sob a óptica da geotectônica foi apresentada por Brito Neves e Albuquerque. De lá para cá, a observação continuada, mais a aquisição de novos dados quantitativos e qualitativos de poços - e a proveitosa discussão com colegas - que trabalham em diferentes circunstâncias geotectônicas - se somaram como matéria e motivação para este texto.

Há muitos campos novos do conhecimento em progresso na geologia estrutural, em termos de locação de poços, na opção por outros tipos de captação (nem sempre o poço tubular vertical é o meio indicado na engenharia de poços). Reconhecemos a fartura de temas em progresso. Várias teses de doutoramento e muitas outras publicações em encontros científicos e em revistas especializadas podem ser contabilizadas. Já é tempo e já há massa crítica suficiente para reunir todo este conhecimento gradativamente acumulado de diferentes frentes de pesquisa e tentar consolidá-lo num compêndio específico.

O objetivo deste trabalho é um exercício tentativo preliminar de condensação, e com isto procurar ajudar na identificação dos melhores sítios de acumulação e circulação de águas subterrâneas com a introdução da variável geotectônica e, conseqüentemente, contribuir na escolha dos melhores locais para captação de água subterrânea (poços), tendo em vista os aspectos quantitativos e qualitativos.

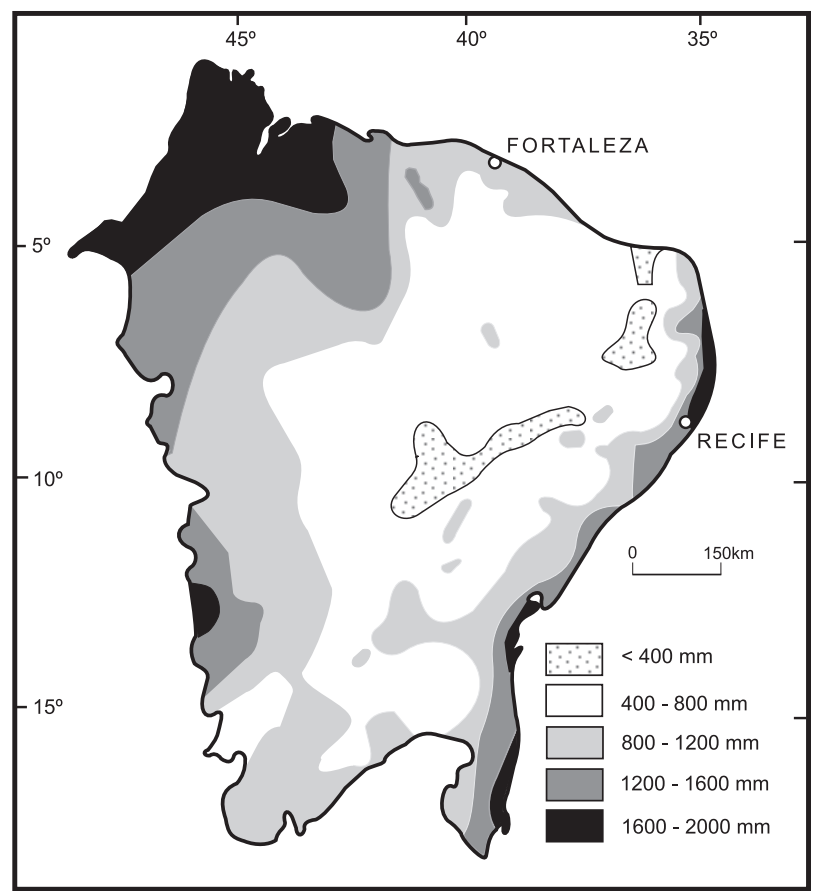

Figura 2. Mapa de isoietas, período 1912 - 1989, médias anuais consolidadas pelo MINTER/SUDENE. Comparar com a Figura 3 (evaporação potencial). 


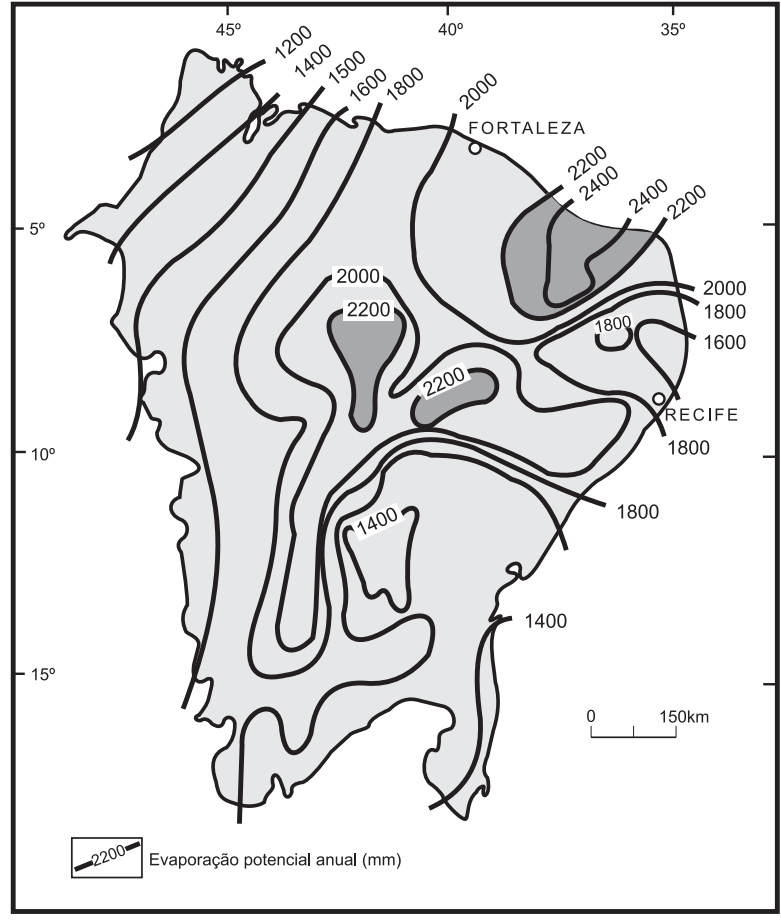

Figura 3. Mapa de evaporação potencial em $\mathrm{mm} / \mathrm{ano}$ Dados auferidos junto ao MINTER/SUDENE.

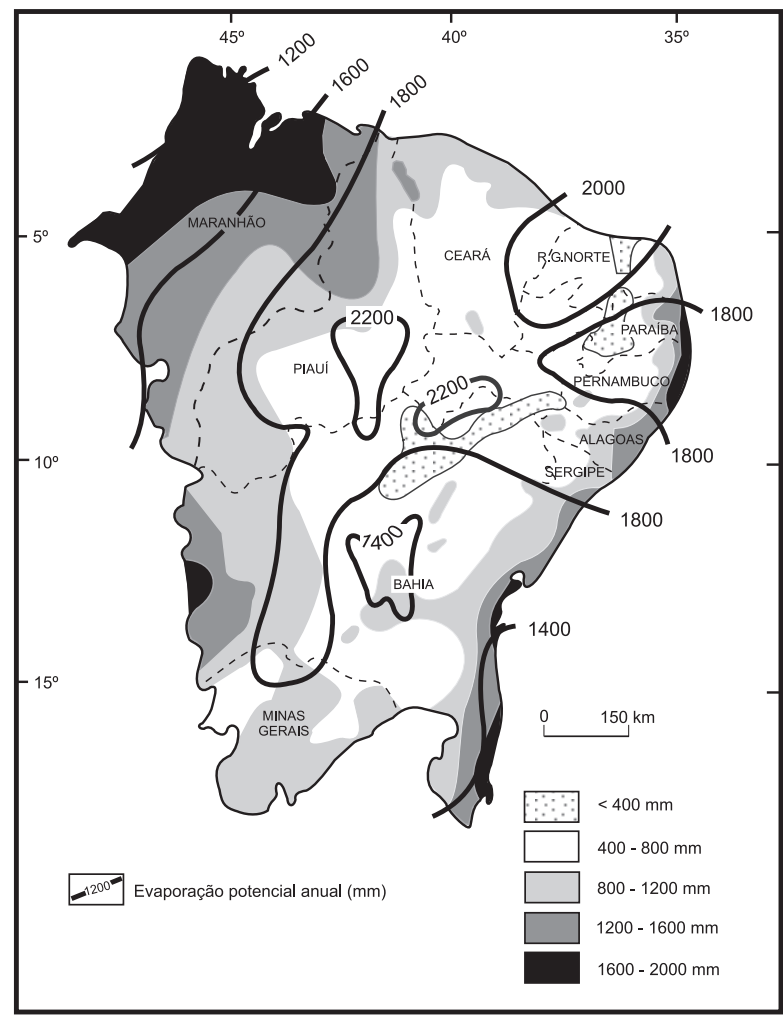

Figura 4. Mapa de qualidade (TSD $=\mathrm{mg} / \mathrm{L}$ ) das águas subterrâneas da Província Borborema, extraído do trabaIho de Cruz e Melo (1968), dados do MINTER/SUDENE.
Este trabalho foi apresentado oralmente, a convite, na International Conference on Groundwater in Fractured Rocks, realizada pela IAH/UNESCO, na República Checa, em setembro de 2003, em cujos Proceedings (p. 33 - 34) consta um resumo expandido.

\section{ANÁLISE DOS FATORES/VARIÁVEIS A SEREM CONSIDERADOS (QUADRO 1)}

Neste trabalho, desde a introdução já se reconheceu que o clima e a fisiografia são fatores/variáveis importantes na formação e no potencial hídrico de reservatórios subterrâneos.

Cabe agora destacar e chamar atenção para a faceta de regionalização tectônica (Figuras 1 e 5), e que esta deve ter um papel de primazia e privilégio no desenvolvimento de todos os outros temas concernentes às águas subterrâneas do Sistema Cristalino. A pretensão é destacar o grupo de variáveis da Geotectônica, de forma que - para as mesmas condições de clima e fisiografia - se possa diagnosticar resultados/produção, desde que os fatores dependentes do homem (escolha da locação e forma de captação, engenharia, manutenção e uso dos poços) possam ser monitorados e aprimorados ao máximo.

Os sete tipos (Quadro 2, Figura 5) de condições aquíferas do Sistema Cristalino aqui postulados (e que permitem subdivisões) são relativos apenas ao universo do setor oriental do escudo Atlântico. A sistematização geotectônica de diferentes tipos crustais e associações estruturais (Hobbs et al., 1976, entre outros) certamente levarão ao reconhecimento/identificação de outras condições aqüíferas alhures. A primazia reclamada para esta óptica de observação evoca e parafraseia a clássica assertiva de Read (no tocante aos granitos): há condições aqüíferas e condições aqüíferas no sistema cristalino a serem consideradas. A identificação e proposição de sete tipos distintos (Figura 5) de condições aqüíferas são, certamente, uma primeira aproximação de um problema, podendo vir a ser incrementada substancialmente (as possibilidades de subdivisão e/ou de junção de tipos ficaram em evidência), ou pode vir a ser reduzido este número na dependência de estudos futuros e da procura de um consenso.

O que deve ficar muito bem marcado de nossa proposta é a diversidade extraordinária do sistema aquíf́ero, o que tem implicações científicas (combater o simplismo corrente do tratamento) e práticas, como fugir um pouco das generalizadas sistemáticas de locações de poços tubulares verticais e aduzir propostas de outros tipos de captações. Claro está que a comprovação e o melhor desempenho destes propósitos andará pari passu com a execução de adequados "projetos de poços" (well design), incluindo fases desde a locação, passando pela operação e manutenção, e chegando ao uso do poço. 
Quadro 1. Principais grupos de variáveis atuantes no Sistema Aqüífero Cristalino e na produtividade dos poços.

\begin{tabular}{|l|l|}
$\begin{array}{l}\text { GEOTECTÔNICA } \\
\text { (Dinâmica Interna) }\end{array}$ & $\left.\begin{array}{l}\text { Tipo crustal } \\
\text { Posição tectônica } \\
\text { Assembléias litológicas } \\
\text { Associações estruturais } \\
\text { Ativação cenozóica sobreposta } \\
\text { Coberturas sedimentares }\end{array}\right\}$ Paleotectônica \\
$\begin{array}{l}\text { CONDIÇÕES CLIMÁTICAS } \\
\text { (Dinâmica Externa) }\end{array}$ \\
$\begin{array}{l}\text { Pluviometria (taxas anuais, distribuição, duração e intensidade) } \\
\text { versus } \\
\text { Evapo-transpiração } \\
\text { Umidade do ar } \\
\text { Fluxo superficial e possibilidade de recarga (infiltração) }\end{array}$ \\
$\begin{array}{l}\text { CARACTERÍSTICAS } \\
\text { (a participação/intervenção } \\
\text { do homem) }\end{array}$ \\
$\begin{array}{l}\text { Escolha do "well site" } \\
\text { Locação (obtenção de melhor condutividade hidráulica) } \\
\text { "Well design" } \\
\text { Construção } \\
\text { Desenvolvimento } \\
\text { Uso e manutenção }\end{array}$ \\
\hline
\end{tabular}

A

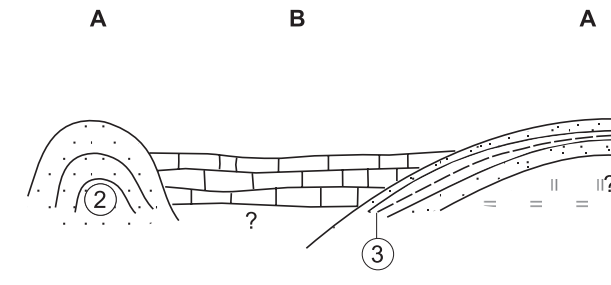

A

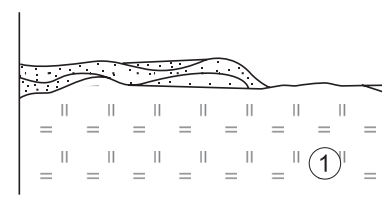

C A
$\left(F^{\prime}\right)$
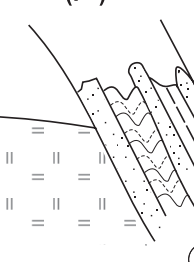

(2)
$\mathbf{F}$

$(\mathrm{F} ")$<smiles>[GeH3]</smiles>

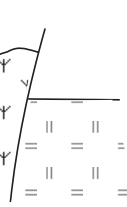

D

D' / E' 
Quadro 2. Principais características e dados dos sistemas aqǘferos cristalinos discriminados para a parte centro-oriental do escudo Atlântico.

\begin{tabular}{|c|c|c|c|c|c|}
\hline $\begin{array}{l}\text { Sistema } \\
\text { Aqüífero }\end{array}$ & $\begin{array}{l}\text { Componentes } \\
\text { Lito-Estruturais }\end{array}$ & $\begin{array}{c}\text { Feições } \\
\text { Destacáveis }\end{array}$ & $\begin{array}{c}\text { Vazão } \\
\text { Específica (Q/s) } \\
\mathrm{m}^{3} / \mathrm{h} / \mathrm{m}\end{array}$ & \begin{tabular}{|c|} 
Qualidade \\
Química \\
Res. Seco: $\mathrm{mg} / 1$
\end{tabular} & $\begin{array}{l}\text { Observações } \\
\text { Adicionais }\end{array}$ \\
\hline $\begin{array}{c}\text { Coberturas Paleo- } \\
\text { Mesoproterozóicas (A) }\end{array}$ & $\begin{array}{c}\text { Assembléias QP }>\text { C: } \\
\text { quartzito-metapelito }>\text { carbonato }\end{array}$ & $\begin{array}{l}\text { Porosidade intersticial, fraturas, } \\
\text { juntas estratigráficas, contatos }\end{array}$ & $\Rightarrow \begin{array}{c}0,5-1,0 \\
25,0\end{array}$ & $0-600$ & $\begin{array}{l}\text { Nível estático raso, localmente } \\
\text { condições de artesianismo }\end{array}$ \\
\hline $\begin{array}{c}\text { Coberturas } \\
\text { Neoproterozóicas (B) }\end{array}$ & $\begin{array}{c}\text { Assembléias C > QP: } \\
\text { carbonato, metapelito, quartzito }\end{array}$ & $\begin{array}{l}\text { Porosidade de fraturas }= \\
\text { dissolução cárstica } \\
\text { Clivagem ardosiana local }\end{array}$ & $\begin{aligned} & 0,5-0,8 \\
\longrightarrow & 4,0-6,0\end{aligned}$ & $\begin{array}{l}500-1.000 \\
1.000-2.000\end{array}$ & $\begin{array}{c}\text { Q/s cresce com a intensidade } \\
\text { do fraturamento ( f(int.dobramento)) } \\
\text { e da dissolução }\end{array}$ \\
\hline $\begin{array}{l}\text { Thrust-and-fold-belts (C) } \\
\text { e Faixas Marginais (D) }\end{array}$ & $\begin{array}{c}\text { Assembléias QPC + } \\
\text { metadiamictitos e metaturbiditos }\end{array}$ & $\begin{array}{c}\text { Como acima, } \\
\text { metacarbonatos e clivagem } \\
\text { ardosiana muito importantes }\end{array}$ & $\Rightarrow \begin{array}{l}0,5-2,0 \\
\Rightarrow \quad 15,0-350,0\end{array}$ & $500-2.000$ & $\begin{array}{c}\text { Como acima, falhamentos } \\
\text { locais importantes } \\
\text { Podem constituir os melhores } \\
\text { de todos os aqüiferos (em produção) }\end{array}$ \\
\hline $\begin{array}{c}\text { Faixas Móveis } \\
\text { Interiores (distais) (E) }\end{array}$ & $\begin{array}{l}\text { Xistos diversos, metarcóseos, } \\
\text { metavulcânicas (bimodais): } \\
\text { Assembléias BVAC > e QPC }\end{array}$ & $\begin{array}{c}\text { Serranias de quartzitos (E') } \\
\text { e altos graníticos (E") são } \\
\text { diferenciados } \\
\text { Idem, a presença de } \\
\text { metapsamitos e metacarbonatos }\end{array}$ & $\Rightarrow \begin{array}{c}0,1-0,2 \\
\quad 1,5\end{array}$ & $\Rightarrow 2.000-5.000$ & $\begin{array}{c}\text { Em geral, condições drásticas } \\
\text { Algumas feições orográficas } \\
\text { (serranias + pluviosidade associada) } \\
\text { e litológicas podem minimizar a } \\
\text { severidade das condições }\end{array}$ \\
\hline $\begin{array}{l}\text { Embasamento dos crátons, } \\
\text { dos "maciços" (inliers) } \\
\text { e das faixas móveis (F) }\end{array}$ & $\begin{array}{l}\text { "Terrenos de alto grau": ortognaisses, } \\
\text { migmatitos, granitos. Restos de } \\
\text { supracrustais vulcano-sedimentares } \\
\text { (TAG + TBG) }\end{array}$ & $\begin{array}{c}\text { Como acima, } \\
\text { serranias quartzíticas }\left(F^{\prime}\right) \\
\text { e graníticas }\left(F^{\prime \prime}\right) \text { constituem } \\
\text { zonas diferenciadas }\end{array}$ & $\Rightarrow \begin{array}{c}0,1-0,2 \\
1,5\end{array}$ & $\Rightarrow \begin{array}{r}>2.000 \\
\Rightarrow \quad 10.000\end{array}$ & $\begin{array}{c}\text { Como acima, só algumas } \\
\text { circunstâncias especiais locais } \\
\text { podem amenizar as drásticas } \\
\text { condições gerais }\end{array}$ \\
\hline $\begin{array}{l}\text { Shear Zones / (G) } \\
\text { Lineamentos }\end{array}$ & $\begin{array}{l}\text { Rochas cataclásticas, s. I. } \\
\text { Extensões de centenas de } \\
\text { quilômetros e até } 20 \mathrm{~km} \text { de largura } \\
\text { Comportamento policíclico }\end{array}$ & $\begin{array}{c}\text { Fraturas "T" importantes } \\
\text { Idem, sobreposição de campos } \\
\text { de esforços tracionais meso } \\
\text { e cenozóicos }\end{array}$ & - & ------ & $\begin{array}{l}\text { Zonas potenciais de formação } \\
\text { de sistemas aqüíferos, principalmente } \\
\text { em zonas extensionais modernas } \\
\text { Não há ainda massa crítica de dados } \\
\text { para expressar valores de qualidade } \\
\text { e quantidade }\end{array}$ \\
\hline
\end{tabular}

Obs: $\Rightarrow$ indicação de valores máximos obtidos, acima das médias e modas. 


\section{COBERTURAS SILICICLÁSTICAS DE PLATAFORMA - A -}

As coberturas dobradas de plataforma, de idade neopaleoproterozóica e mesoproterozóica são representadas pelas rochas siliciclásticas do Supergrupo Espinhaço na Bahia e em Minas Gerais.

São assembléias litológicas do tipo QP > C (quartzitos, pelitos > carbonatos) de variadas procedências paleogeográficas (fluvial, eólico, transicional, marinho raso). Estas coberturas se encontram desde moderadamente dobradas, formando extensos panoramas de planaltos de cotas elevadas (> $800 \mathrm{~m}$ ), até intensamente deformadas (formando serras quartzíticas), como na porção norte-ocidental do Espinhaço, com grau de transformação termodinâmica variável, desde anquimetamorfismo até a facies dos xistos verdes, e só raramente atingindo facies mesozonais.

Este condicionamento aquífero é formado por porosidade mista, de interstícios e de fraturamento, de juntas de estratificação e de contatos. O nível estático é geralmente interceptado nos vales e depressões encaixados no sistema, possibilitando a formação de muitos tipos de fontes (Foto 1) e outras exsudações no contexto das escarpas topográficas. Predominam condições de aqüíferos livres, mas localmente há níveis de aqüíferos confinados, com francas possibilidades de surgência. Também há a formação de aqüíferos suspensos nos pacotes metassedimentares em relevo.

Ao longo de uma extensão longitudinal próxima a $1.200 \mathrm{~km}$, este cortejo de planaltos quartzíticos atravessa diferentes circunstâncias de clima, com taxas anuais de pluviometria bastante variáveis (de $600 \mathrm{~mm} /$ ano a trechos acima de $1.200 \mathrm{~mm} / \mathrm{ano}$ ), havendo sempre ocorrência de águas in descensum (muitas destas são áreas divisórias de cursos d'água), onde as facilidades de captação são muitas (de muitas formas, sem necessidade de perfurações), resultando numa pequena demanda por poços tubulares.

Os tratos livres do aquíf́ero produzem através de poços tubulares Q/s quase sempre acima de $500 \mathrm{~L} / \mathrm{h} / \mathrm{m}$ (variações entre 500 a $1.000 \mathrm{~L} / \mathrm{h} / \mathrm{m}$ são usuais, com a vantagem adicional de serem águas de excelente qualidade química (TDS entre 0 e $600 \mathrm{mg} / \mathrm{l})$ ). De uma maneira geral, aprimorando-se os critérios de locação e os de construção de poços, é possível incrementar consideravelmente estes valores de Q/s, e seria possível instalar programas pilotos de melhor aproveitamento destes recursos hídricos, incluindo recolonização de populações de outras áreas menos aquinhoadas.

$\mathrm{Na}$ zona de interação com a cobertura cratônica e/ou com o thrust-and-fold-belt (Figura 5, entre A e B e Foto 2) a serem discutidos - se encontra o lugar geométrico ideal de grandes possibilidades exploratórias (com algumas experiências concretas), com artesianismo inclusive, pelas circunstâncias estruturais (monoclinal dos quartzitos sotopondo-se aos diamictitos, pelitos e carbonatos do Grupo Bambuí) e de tipos de porosidade ali formados. Somam-se a este quadro de vazios intergranulares juntas, contatos, fraturas geradas pela falha de rejeito oblíquo e discordância angular e erosiva entre as seqüências do Bambuí (sobreposto) e Chapada Diamantina.

Esta zona de contatos mais ou menos linear é vista como um lugar ideal para pesquisa exploratória aplicada, visando a obtenção de vazões elevadas, para projetos de irrigação e mesmo de recolonização, tendo em vista que, sobre a cobertura neoproterozóica do Bambuí e sobre o domínio do thrust-andfold-belt (localizados mais para oeste) há zonas de grande aridez e demanda, assistidas insatisfatoriamente por recursos hídricos locais (porções do contexto B a serem discutidas).

\section{COBERTURAS NEOPROTEROZÓICAS - B -}

As coberturas neoproterozóicas, principalmente (mas não exclusivamente) representadas pelo Supergrupo São Francisco, cobrem a área aproximada de $350.000 \mathrm{~km}^{2}$ do Cráton do São Francisco, apresentando diversas gradações entre unidades não dobradas e pouco dobradas (Foto 3) para contextos intensamente dobrados e falhados do thrustand-fold-belt (Foto 2), estes últimos dispostos mais na periferia do cráton e submetidos diretamente aos vetores tangenciais centripetais das faixas móveis marginais.

As litologias predominantes são carbonáticas e pelíticocarbonáticas, com diamictitos subordinados na base da sequiência (D-QPC = diamictito-quartzito, pelito, carbonato), que são os contextos litoestratigráficos desenvolvidos durante a glaciação Sturtiana (unidades glaciais dos grupos Bebedouro, Jequitaí, Macaúbas, Bebedouro e equivalentes) e as invasões marinhas (formações Sete Lagoas, Santa Helena, Lagoa do Jacaré e equivalentes) subseqüentes. As espessuras desenvolvidas variam bastante, uma vez que o embasamento apresentava ondulações e outras irregularidades rupturais e as coberturas neopaleoproterozóicas e mesoproterozóicas refletem essa paleomorfologia, consignando valores de algumas centenas (o que é mais comum) até alguns milhares de metros.

Poços perfurados nas porções moderadamente dobradas desta cobertura apresentam grandes variações nos valores de vazão, pois o fator dissolução cárstica é importante e igualmente, muito variável, fazendo com que se alternem alguns poços de excelentes descargas com outros de produção medíocre. Os fatores de dissolução cárstica aleatória (zonas mais calcíticas) e de incidências locais (Foto 4) de deformação dúctil ou rúptil (caracteristicamente descontínua nestes domínios) comandam os valores de produção dos poços. Valores de Q/s entre $500 \mathrm{e} 800 \mathrm{~L} / \mathrm{h} / \mathrm{m}$ podem ser contabilizados como representativos para os poços desta condição 
do sistema aqüífero, com valores de TDS situando-se entre 500 e $1.000 \mathrm{mg} / \mathrm{L}$. O fator climático é importante nestes valores de produção, havendo valores de vazão bem superiores em Minas Gerais (pluviometria entre $700-900 \mathrm{~mm} / \mathrm{ano}$ ) em relação àqueles registrados na parte central da Bahia, nos chamados chapadões de Irecê (pluviometria anual de $\leq 700 \mathrm{~mm}$ ).

As passagens para domínios moderadamente dobrados também são francamente assinaladas nas vazões produzidas pelos poços, de forma que, de um modo geral, o grau de deformação é um indicador interessante que pode ser seguido desde as zonas menos deformadas (menores vazões específicas) até aquelas zonas definitivamente inseridas no contexto do thrust-and-fold-belt, onde as descargas específicas dos poços são maiores (valores acima de $6 \mathrm{~m}^{3} / \mathrm{h} / \mathrm{m}$ ). Nas zonas de contato (Foto 2), onde estas coberturas se sobrepõem estratigraficamente àquelas neo-paleoproterozóicas e mesoproterozóicas (A) ocorrem excelentes condições de armazenamento e de produção de águas subterrâneas, inclusive com artesianismo, como voltará a ser discutido neste trabalho.

\section{THRUST-AND-FOLD-BELTS - C -}

Como já mencionado, há vários tipos de transições entre a cobertura neoproterozóica não dobrada e dobrada, e destas últimas para autênticos thrust-and-fold-belts e as faixas móveis marginais, como se tentou mostrar na Figura 5 anexa (vide tratos $\mathrm{B}, \mathrm{C}$ e D).

Trata-se de um arrasto com deformação significativa das sequiências sedimentares (trato B), descoladas por sobre o substrato cratônico. A deformação produz exemplos notáveis de nappismo, deformação isoclinal recumbente etc. O condicionamento estrutural e, conseqüentemente, hidrogeológico mostram diferenças importantes quando se passa de um domínio a outro. E este domínio, intensamente submetido a encurtamento crustal, pelos resultados obtidos (em termos de $\mathrm{Q} / \mathrm{s}$ ), é o mais privilegiado dos condicionamentos aquíferos do Sistema Cristalino de toda região nordeste do Brasil.

Do ponto de vista de assembléias litológicas predomina o tipo D-QPC (diamictitos-quartzitos, carbonatos e pelitos). As feições estruturais de dobras e cavalgamentos vergentes centripetamente se fazem na facies xistos verdes baixo, em nível crustal naturalmente muito raso. As feições de deformação, dobramentos e fraturamentos, são vistas em diversas escalas, de mão, de afloramento (Fotos 5 e 6 ) e de análise geológica/mapeamento regional (Foto 2).

Há dados seguros que demonstram que os valores de produção crescem substancialmente - mantidas as mesmas condições geológico-estruturais gerais - quando do acréscimo (maior presença relativa) de unidades ardosianas, e também quando do acréscimo das taxas de pluviometria média anual. Da região central da Bahia (Irecê e adjacências) para o centro-leste de Minas Gerais (vale do Rio Verde Grande), há um incremento notável nas capacidades específicas médias, desde valores de 500 a $1.000 \mathrm{~L} / \mathrm{h} / \mathrm{m}$ (primeira área) até valores médios de $2.000 \mathrm{~L} / \mathrm{h} / \mathrm{m}$ (segunda área). Em geral, os valores de TDS ficam entre 500 e $1.000 \mathrm{mg} / \mathrm{L}$, sendo águas de boa qualidade para o consumo humano e animal, com raras exceções.

Além de serem condições aqüíferas excelentes, reveladas pelos poços de maiores valores de capacidade específica conhecida $(500<\mathrm{Q} / \mathrm{s} \leq 2.000 \mathrm{~L} / \mathrm{h} / \mathrm{m})$, há, localmente, poços notáveis, com produção de até $700.000 \mathrm{~L} / \mathrm{h}$, com rebaixamento muito pequeno, da ordem de centímetros (BRAZPOÇOS, Belo Horizonte, informação escrita). Na área de contato/falha com as coberturas paleo-mesoproterozóicas, este sistema de cavalgamentos centrípetos condiciona uma zona de artesianismo (Foto 2), onde são conhecidos poços de capacidade específica superior a $25.000 \mathrm{~L} / \mathrm{h} / \mathrm{m}$ (GEOCOMERCIAL, Salvador - BA, informação escrita). Estes dois casos excepcionais foram visitados pessoalmente pelo autor sênior.

Há concretas possibilidades de melhorar as locações, de uma maneira geral, com levantamentos geológicos apropriados (na escala de detalhe) e apoio de prospecção geofísica elementar (métodos de eletro-resistividade, por exemplo). É possível, com estes procedimentos, vir a incrementar substancialmente e dotar de maior regularidade a produção de poços locados nestes contextos (zona entre A e B, Figura 1) do sistema aqüífero.

\section{FAIXAS MÓVEIS MARGINAIS - D -}

As faixas ditas marginais ou proximais são aquelas situadas na periferia dos núcleos cratônicos, guardando, de certa forma, relações e conexões (mesma lito-estratigrafia) com of foreland thrust-and-fold-belt e com a cobertura cratônica (B, Figura 5). De forma que, nas partes mais externas destas faixas móveis, há uma série de litologias (assembléias do tipo D-QPC) consideradas favoráveis ao armazenamento de água subterrânea, como diamictitos, filitos, ardósias, cálcio-filitos, calcários, metapsamitos diversos, metaturbiditos etc. Assim, estes contextos podem ser diferenciados como condições especiais e distintas do Sistema Aquífero Cristalino, de certa forma próxima dos tipos B e C dantes considerados; e francamente distinta, reunindo condições algo bem melhores que aquelas dos sistemas interiores (E, Figura 5), a serem tratadas na seqüência.

Geralmente, estas faixas têm dobramento relativamente simples, monofásico ou não, vergente para o cráton, crescente em intensidade (juntamente com o grau de metamorfismo) na medida que se afasta do cráton, quando cada vez mais elas se aproximam das condições estruturais 


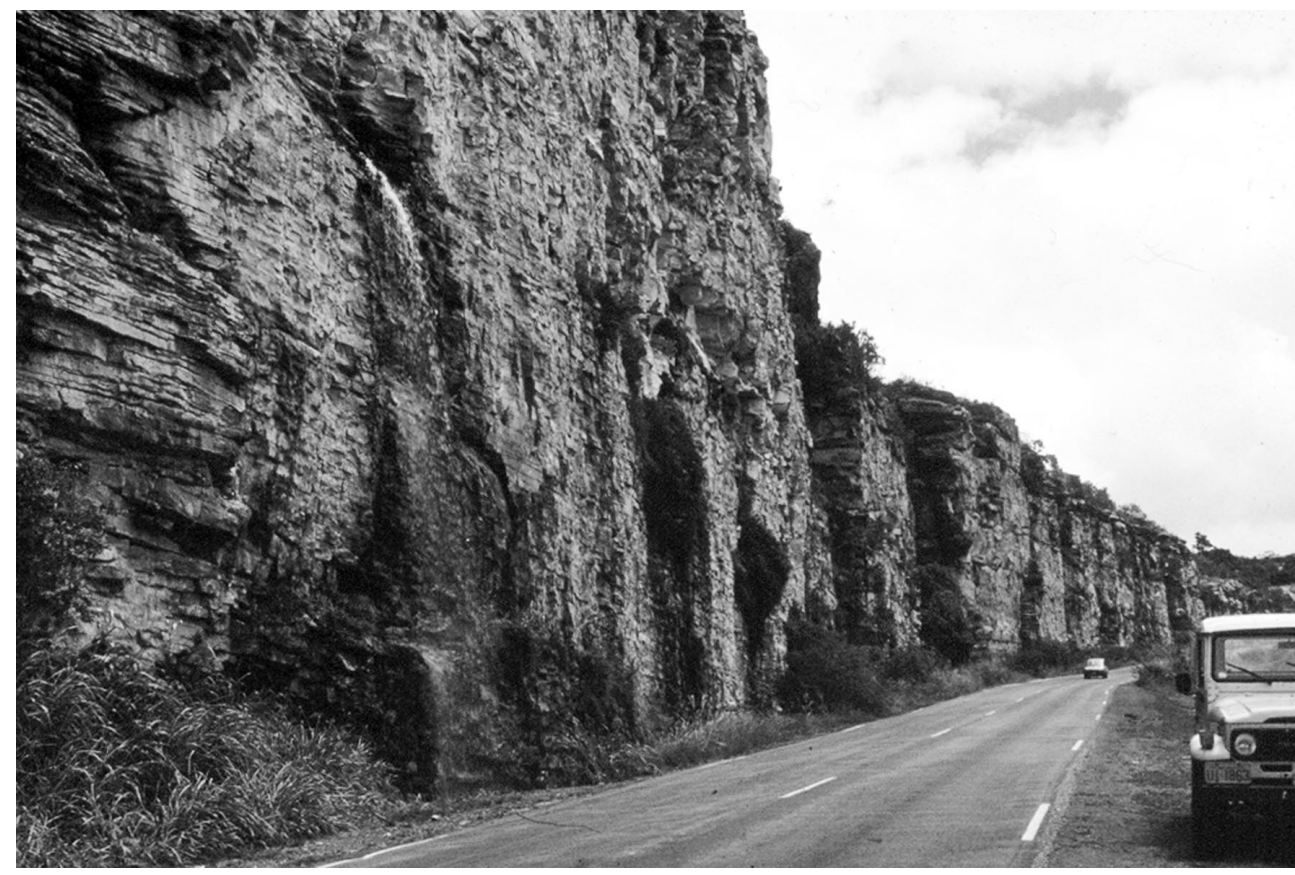

Foto 1. A Formação Tombador, na serra topônima, a oeste de Jacobina - BA. Após o período chuvoso, inúmeras fontes de depressão ao longo da escarpa. Metassedimentos provavelmente do Mesoproterozóico (Figura 5 - Unidade A).

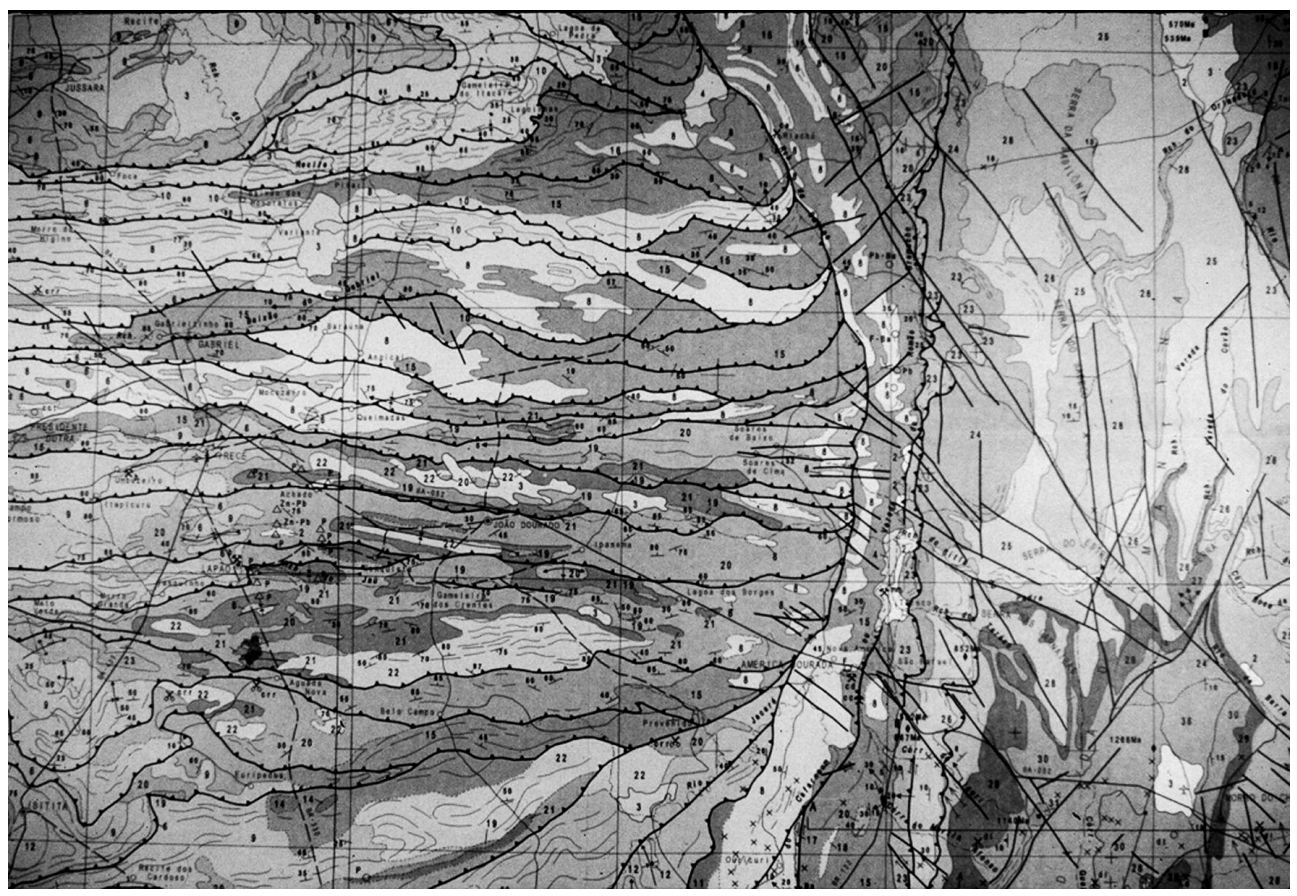

Foto 2. Zona de contato discordante (erosão e deformação) e falhado (arrasto sinistral) do anticlinal da Serra da Babilônia (Grupo Chapada Diamantina), a leste, com a seqüência pelítico-carbonática (diamictitos subordinados) do supergrupo Bambuí, no thrust-and-foldbelt ao longo da Vereda Romão Gramacho. Fonte: Sampaio et al. (1997). 
e metamórficas das faixas interiores (há algumas situações transicionais entre os tipos D e E). O metamorfismo varia da facies xistos verdes baixo até a facies anfibolito, acompanhando a intensificação do dobramento.

O contexto de vazios desenvolvido engloba: fraturamento, contatos, dissolução cárstica, clivagem ardosiana, e, provavelmente, alguma porosidade intersticial, outorgando às rochas uma condição favorável de acumulação e circulação de água subterrânea. A capacidade específica média dos poços perfurados nestas faixas móveis especiais (próximas dos crátons) é da ordem de $500 \mathrm{~L} / \mathrm{h} / \mathrm{m}$ (podem atingir até $2.000 \mathrm{~L} / \mathrm{h} / \mathrm{m}$ ), o que configura, regra geral, valores sempre superiores aos valores das faixas móveis interiores ou distais dos crátons (tipo E).

Além destas características, nestas faixas marginais também eventualmente se desenvolvem altos quartzíticos (D') e serranias graníticas (D”), que são feições suplementares de melhoria das condições gerais, a serem discutidas $a$ posteriori, onde há participação significativa de contingentes de águas vadosas, com fontes e exsudações outras.

Algumas faixas apresentam restos esparsos de coberturas cambro-ordovicianas (do chamado "Estágio de Transição"), depósitos pós-orogênicos, geralmente consideradas como "molassas". Estes sedimentos clásticos (às vezes com vulcanismo intermediário importante), apesar de ocorrerem de forma restrita, residuais de erosão, funcionam como catalizadores da infiltração e, localmente, podem constituir contextos aqüíferos auxiliares importantes, mais próximos das condições hidrogeológicas gerais das rochas sedimentares.

\section{FAIXAS INTERIORES OU DISTAIS: TERRÍGENAS/VULCANO- SEDIMENTARES - E -}

As faixas interiores (distais dos crátons) são constituídas de variadas associações metassedimentares $(\mathrm{QPC}=$ quartzitos, pelitos, carbonatos subordinados, de forma minoritária; BVAC = vulcânicas bimodais, arcóseos, conglomerados etc.) de águas rasas e profundas, consorciadas com vulcanismo diversificado (ácido, intermediário e básico), em facies metamórficas variáveis da zona dos xistos verdes para zonas da facies anfibolito alto (migmatização é processo comum). Estas faixas móveis são as que se apresentam entre as mais difíceis de condições de jazimento e de circulação de águas subterrâneas, principalmente naquelas zonas onde as condições climáticas são mais rigorosas (baixa pluviometria, altas taxas de evapo-transpiração etc.). E são muitos os casos, no polígono das secas, onde estas condições geológicas e climatológicas desfavoráveis atuam em conjunto.

Tratam-se de rochas metamórficas polideformadas, embasando áreas de pediplanos de peneplaníceis com pouca vegetação, e drenagem intermitente que, regionalmente, funcionam como aqǘfugos (numa primeira análise). As porções aquíferas destas rochas, originalmente impermeáveis, são bastante localizadas, restritas e de dimensões modestas, e são condições resultantes da formação localizada de uma permeabilidade de fraturas, associada ou não, a uma porosidade intersticial de coberturas intempéricas ou aluviais que Albuquerque $(1984,2003)$ denominou de "zona aqüífera" e Gustáfson e Krásny (1994) chamaram de "condutor hidráulico".

Em contextos de rochas ígneas e metamórficas diversas, a tendência dos geólogos tem sido procurar as rochas ditas mais favoráveis (quartzitos, vide Foto 7, calcários, metacórseos, metaconglomerados, metafelsitos etc.), por apresentarem, ainda, alguma porosidade intergranular ou cárstica. Mas, a ocorrência destas rochas é, geralmente, minoritária (QPC $<<$ BVAC) nas faixas móveis interiores, distais dos núcleos cratônicos. Nestas situações, os hidrogeólogos procuram identificar as citadas zonas aquíferas, valendo-se de elementos da geologia estrutural e da geotectônica (com adicionais e vários recursos do sensoriamento remoto) e de outras circunstâncias geológico-geográficas a fim de chegarem aos sítios favoráveis (em verdade, menos desfavoráveis) ao armazenamento e à circulação de águas subterrâneas, objeto da locação de poços.

A pesquisa nestes terrenos constitui o maior desafio da hidrogeologia do sistema aqüífero cristalino, que imprescinde de um bom conhecimento geológico (com ênfase à caracterização tectônica e estrutural) e hidrogeológico regional.

No Quadro 2, se verifica claramente que estes tipos de terrenos estão entre os mais problemáticos em termos de produtividade hídrica $(\mathrm{Q} / \mathrm{s}$ variando de 100 a $200 \mathrm{~L} / \mathrm{h} / \mathrm{m}$ nos poços produtivos). Além do que, deve ser registrado que há grande número de poços praticamente secos e abandonados, por razões primárias (vazões irrisórias, alta salinidade) e secundárias (inexistência de um mínimo de manutenção). Devido à dificuldade de circulação, as águas destes terrenos são muito salinizadas, havendo um grande percentual de poços com águas com sólidos totais dissolvidos (STD) superior a $1.500 \mathrm{mg} / \mathrm{L}$, com muitos casos de poços com $6.000 \mathrm{mg} / \mathrm{L}$ e alguns casos de poços com cerca de $20.000 \mathrm{mg} / \mathrm{L}$ de STD (há alguns raros casos excepcionais locais detectados acima deste valor).

Mas, da experiência no Nordeste, pode-se dizer que este quadro desanimador pode ser atenuado, sem poder se precisar de quanto, pois lamentavelmente na maioria absoluta estes poços foram locados e perfurados sem critérios técnicos corretos, utilizando-se a intuição e, até mesmo, a presunção e a teimosia (dois a três poços seguidos no mesmo sítio). Predominou, na maioria das vezes, o desconhecimen- 


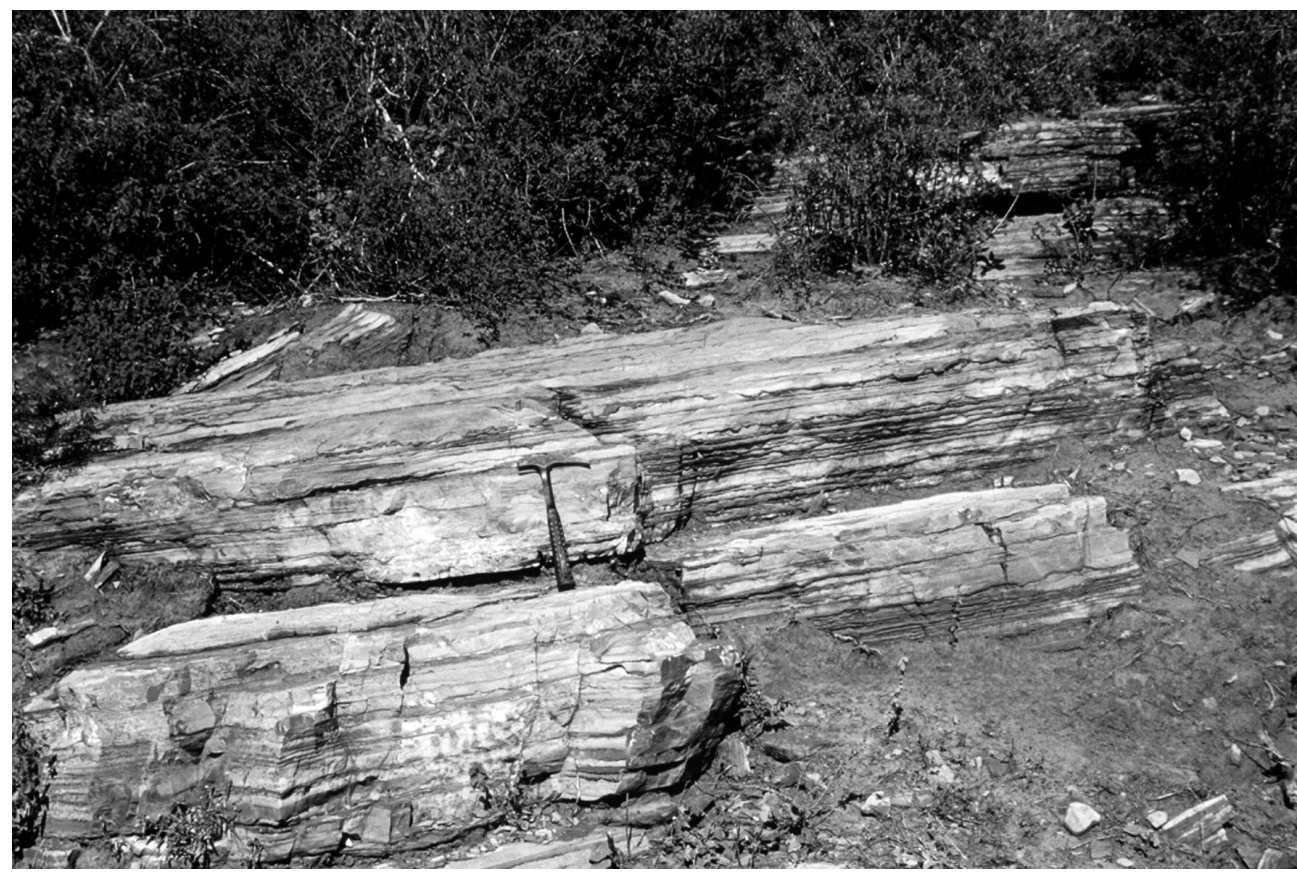

Foto 3. Unidades carbonáticas ("cap dolomites") sobrejacentes a diamictitos, não deformados (Figura 5 - Unidade B), da cobertura cratônica. Povoado de São Rafael, Morro do Chapéu BA. Algumas evidências discretas de dissolução cárstica podem ser observadas.

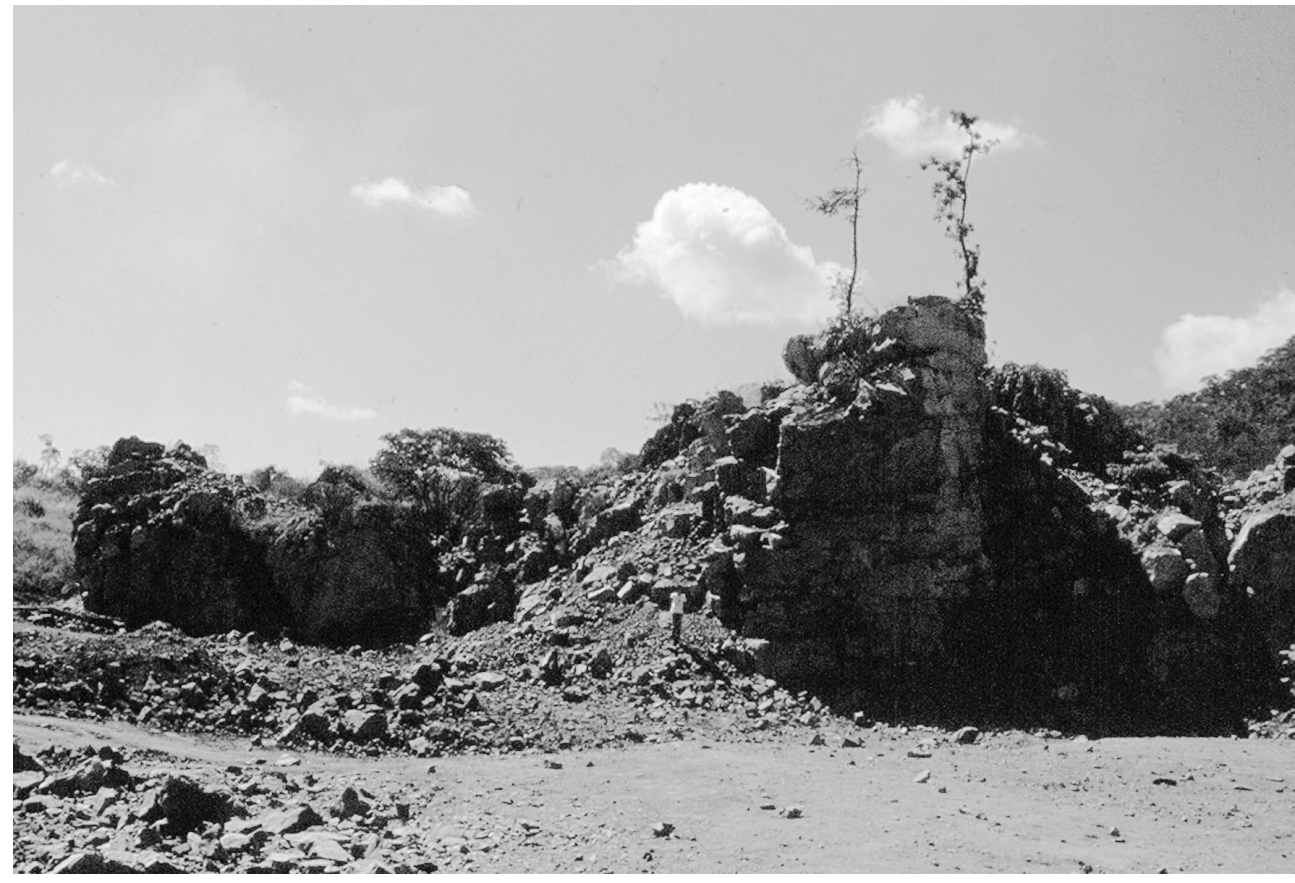

Foto 4. Unidades carbonáticas (Figura 5 - Unidade B) da cobertura cratônica, com incidência local da deformação rúptil, descontínua, sistema de grábens e horstes associados com transcorrência, em Arcos - MG. 


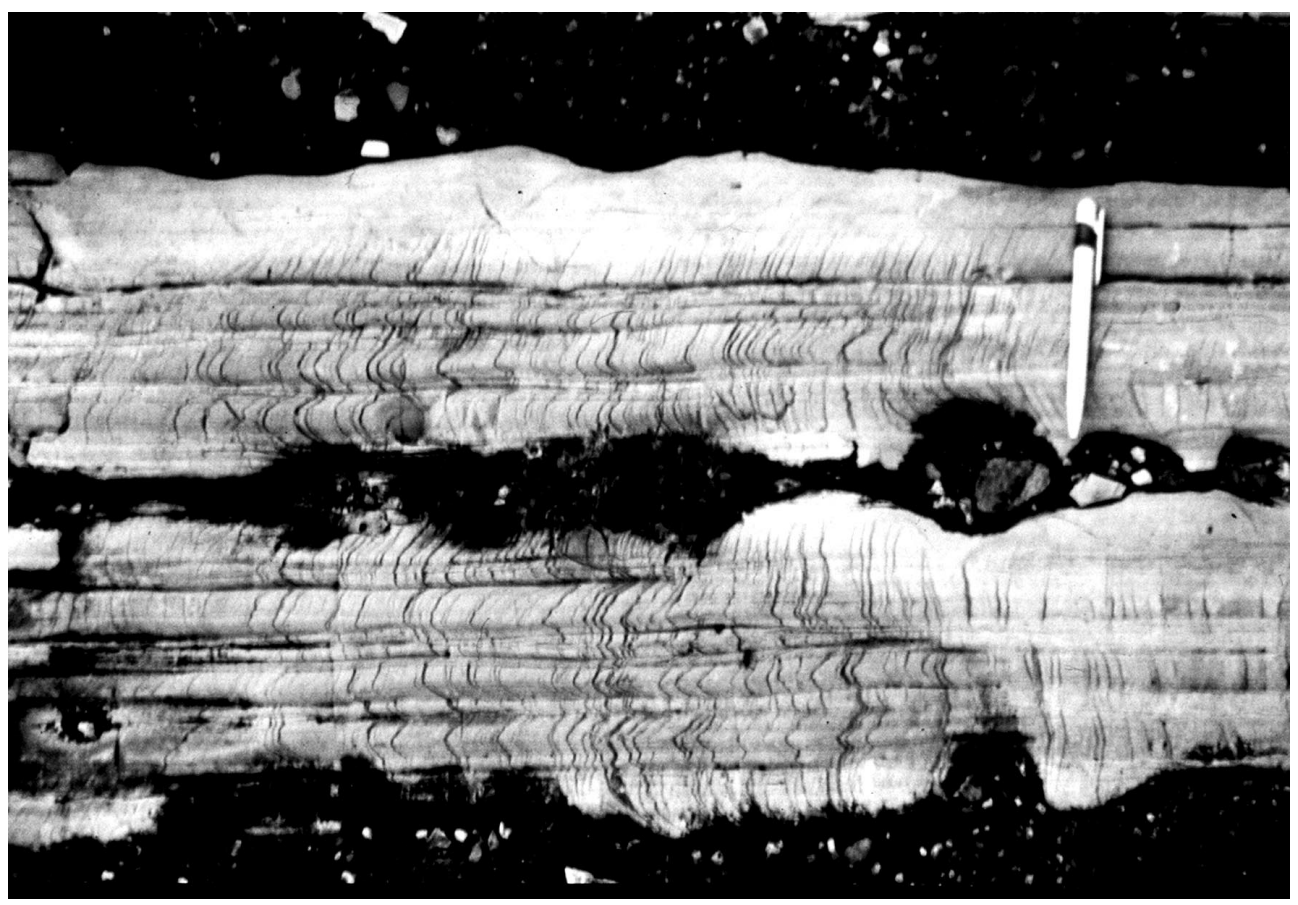

Foto 5. Visão zenital de afloramento da zona central de um anticlinal isoclinal (parasita) do thrust-and-fold-belt. É possível ver a estratificação centimétrica, o fraturamento longitudinal (bc) e o intenso microfraturamento transversal (ac). Lagoa dos Borges, América Dourada - BA.

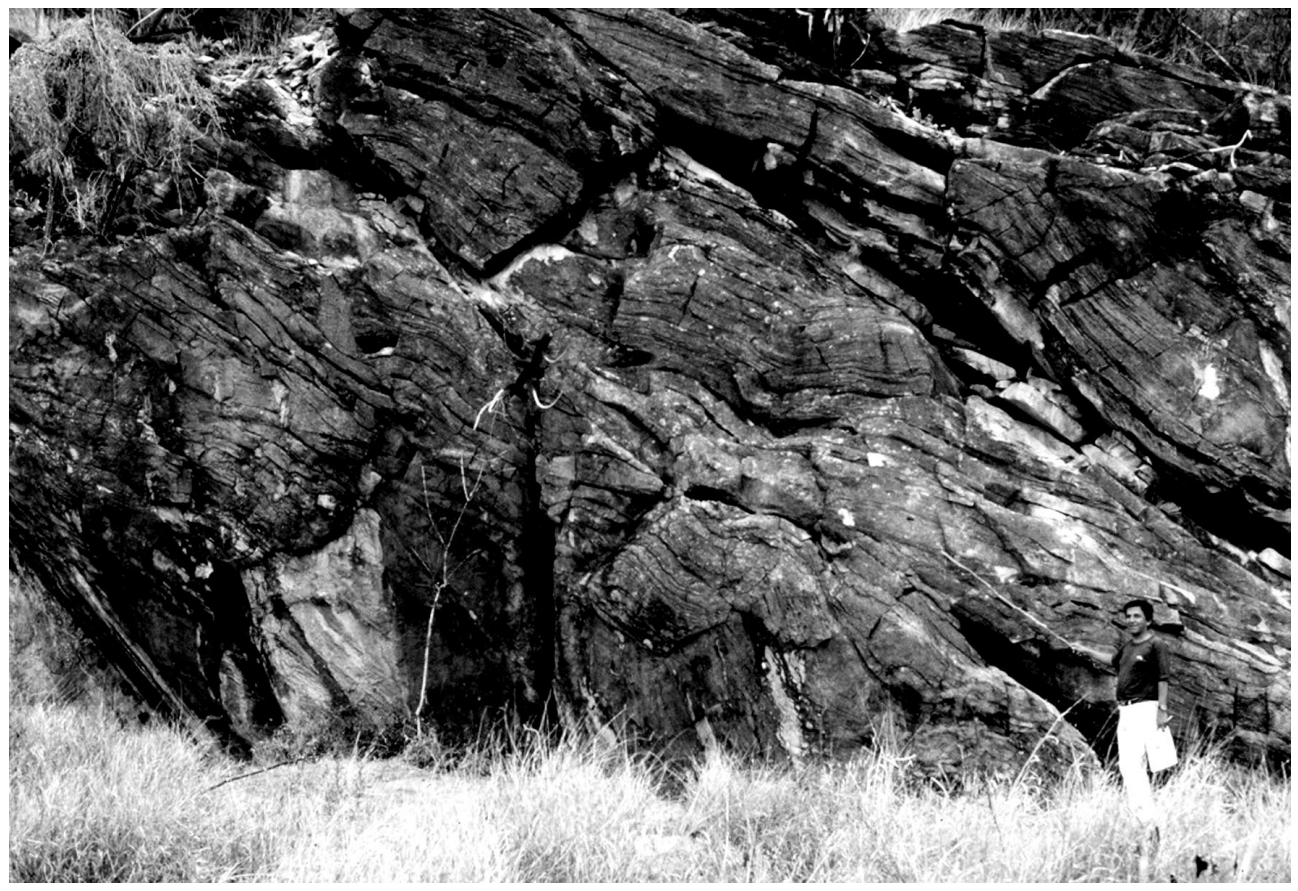

Foto 6. Visão lateral de afloramento de estrutura duplex do thrust-and-fold-belt, com movimentos dirigidos para sul, gerando intenso fraturamento nos calcários do Bambuí. Estrada de América Dourada para Cafarnaum. Realce da dissolução cárstica nos fraturamentos. 
to de todos os princípios propostos no Quadro 1. Com a assistência de um geólogo experimentado, mais da metade destes poços (há um contingente de dezenas de milhares nestas circunstâncias geológicas) não teriam sido locados e perfurados, e que muitos poderiam ter sido deslocado de alguns metros ou alguns quilômetros para circunstâncias geológicas locais mais favoráveis. Isto sem falar nos auxílios adicionais que poderiam ser auferidos de métodos geofísicos, além de que os fatores de construção, desenvolvimento, manutenção e uso, foram geralmente relegados aos níveis mais baixos. De forma que o Quadro 2 mostra uma realidade, mas não pode mostrar também que esta realidade poderia ser outra, menos drástica. Há fatores técnicos, humanos, históricos etc. envolvidos que não se pode expurgar.

Nestes domínios do "cristalino brabo" como se costuma designá-lo (juntamente com as condições tipo F, a serem discutidas a seguir) há alguns casos especiais a serem analisados. Há algumas regiões no interior do nordeste, onde sistematicamente se obtêm poços com água em quantidade e qualidade bastante razoáveis, dentro das possibilidades deste condicionamento do Sistema Aqüífero Cristalino, contrariando expectativa geral de obtenção de resultados desfavoráveis. É o caso da zona caririzeira de Cabaceiras e Boa Vista -PB (no âmbito das condições climáticas mais contundentes, da análise das Figuras 2 e 3) e do sertão do vale do Piancó (na Paraíba), em rochas que são usualmente evitadas para perfuração de poços tubulares, como é o caso dos micaxistos e xistos anfibolíticos. Segundo Albuquerque (2003), isto se deve à maximização dos fatores geotectônicos, com ênfase à ação da Neotectônica, ao que acrescentamos (com observação in loco) que se deve também à ocorrência (saudável e invulgar) de trabalhos regulares de manutenção.

Outro tipo de atenuante nestes domínios cristalinos mais rigorosos é o autêntico "oásis" das serranias quartzíticas (E') e graníticas (E”). As águas in descensum (constituem um manancial notável, através de fontes de depressão, emanações difusas etc.) demoram longo tempo para chegar ao nível estático regional (Foto 8). E estas águas constituem manancial a ser aproveitado, antes de serem consumidas pela evapo-transpiração, por obras singelas de engenharia de captação, o que tem sido feito em alguns casos (de forma precária na maioria das vezes). Nestas "serranias", seja em pediplanos mais elevados, seja em testemunhos de pediplanos já arrasados, verificam-se, muitas vezes, de forma surpreendente e agradável, a presença de águas de boa qualidade (Serra da Baixa Verde - PE - Foto 8, Serra do Pereiro - CE, Meruoca-CE, Serra do Teixeira - PB, Solidão - PE etc.) que costumam drenar a zona serrana, que por si só já é algo diferenciada, como uma espécie de "oásis" climático (pluviometria acrescida pela orografia).

No caso das serranias graníticas e granítico-migmatíticas e das cristas quartzíticas (comuns aos tratos aqui designados
D, E e F), ao lado do panorama de águas vadosas freqüentes, há acumulações temporárias, ora retidas em fraturas elevadas em cota (Fotos 9 e 10), ora se têm casos de acumulação de colúvios nos sopés. E, assim, há a possibilidade adicional de captações outras, bem sucedidas, casos de poços de largo diâmetro ("Amazonas"), galerias de infiltração, destas “águas suspensas" e nestes colúvios (eventualmente a ser somado ao contingente das rochas do substrato). Exemplos disto ocorrem nas serras de Areial - PB (Fotos 9 e 10), Orós - CE, Junco - PB e Jacobina - BA, entre muitos outros. Deve haver antecipação do homem na captação a sequiosidade inexorável das altas taxas de evapo-transpiração.

O diferencial dos fatores clima e fisiografia deve ser mencionado nesta oportunidade, tendo em vista a experiência e observação dos autores em outras regiões/províncias do sudeste do Brasil. Nas mesmas circunstâncias geológicas gerais, de faixas interiores (mesmo contexto lito-estrutural e geotectônico), no sudeste do Brasil (a partir do sul da Bahia), os valores de $\mathrm{Q} / \mathrm{s}$ se aproximam do duplo daqueles encontrados no nordeste (Costa, 1996), com qualidade química muito superior (a excepcional), sem restrições de uso. De forma que a classificação aqui ensejada tem validade regional apenas (semi-árido nordestino), devendo essas diferenças substanciais em qualidade e quantidade (do sul e sudeste) serem creditadas ao condicionamento climático, com ênfase à pluviosidade, mais regular, melhor distribuída, que favorece a recarga, a circulação e a descarga (águas sempre renovadas), tudo isto somado à presença de um manto de intemperismo bem mais espesso (da ordem de dezenas de metros) e favorecedor do condicionamento geral.

\section{EMBASAMENTO DOS CRÁTONS E DOS MACIÇOS - F -}

As condições geológicas gerais do embasamento dos núcleos cratônicos (Cráton do São Francisco), e dos chamados "maciços" (basement inliers, interfaixas interiores e mesmo intrafaixas, Figura 1) são muito semelhantes, tendo em vista que eles são terrenos tectono-estratigráficos originários do mesmo bloco supercontinental (Rodínia do Mesoproterozóico). São contextos lito-estruturais, principalmente de idades arqueanas e paleoproterozóicas, sendo que, no caso dos maciços, há presença freqüente de plutonismo granítico do Neoproterozóico (o que não ocorre no cráton). Em geral, predominam rochas de alto grau, gnáissico-migmatítico-graníticas, com máficas e ultramáficas subordinadas, polideformadas, de nível crustal meso a catazonal. Eventualmente, ocorrem restos de associações vulcano-sedimentares de baixo a médio graus do tipo greenstone-belt e assemelhados.

As condições hidrogeológicas gerais são extremamente difíceis, tanto quanto àquelas das faixas móveis interiores 
(tratos E), em razão dessas rochas desempenharem, regionalmente, o papel de aqüífugos, restringindo-se para condições aqüíferas restritas a apenas alguns trechos fraturados/ falhados/intemperizados desses terrenos, as chamadas "zonas aqǘferas" de Albuquerque $(1984,2003)$. Esta condição é exacerbada pelo fator hidroclimático adverso, o que se traduz na baixa produtividade dos poços já perfurados, dados por valores de $\mathrm{Q} / \mathrm{s}$ muito baixos, entre $100 \mathrm{e}$ $200 \mathrm{~L} / \mathrm{h} / \mathrm{m}$, incluindo além disto um percentual significativo de poços secos e abandonados.

Em todos estes aspectos guardam semelhanças com aqueles contextos desfavoráveis descritos para as faixas móveis interiores (E). A separação feita/postulada é devido ao contingente de rochas de alto grau, pela natureza distinta dos domínios lito-estruturais e pelo quadro geotectônico regional. Mas, é possível que, para o futuro, se possa ter dados e parâmetros mais eficazes a partir de pesquisas hidrogeológicas para ratificar de forma mais concreta a discriminação aqui proposta.

A qualificação química das águas subterrâneas destes terrenos, pelos dados até o presente disponíveis, também segue o mesmo parâmetro encontrado nas faixas móveis interiores. Devido ao fato de que grande parte das zonas de alto grau estarem em regiões/zonas de condições climáticas rigorosas (nordeste do cráton do São Francisco, maciço de Sobradinho/noroeste da Bahia - sudoeste de Pernambuco, maciço do Rio Piranhas/leste do Rio Grande do Norte e Paraíba), onde são comuns os elevados valores de resíduo seco (vide Cruz e Mello 1986, Figura 4), há uma tendência de creditar a estes terrenos a condição de mais problemáticos em termos de águas subterrâneas no cristalino. Mas, em termos de dados estatísticos (são poucos ainda), não há valores suficientes, nem sistemática de apreciação, para ratificar esta discriminação.

Da mesma forma como verificado nas faixas interiores, há algumas exceções a esse quadro geral adverso. Caso de alguns autênticos "oásis" a serem destacados nestes terrenos de alto grau. São novamente as serranias quartzíticas $\left(\mathrm{F}^{\prime} ;\right.$ e. g. Serra de Jacobina, já destacada) e os "altos" graníticos ( $\left.\mathrm{F}^{\prime}\right)$, como, por exemplo, ao longo do Sienito de Itiúba, na Bahia, e de unidades graníticas neoproterozóicas formando "serras" no interior do Rio Grande do Norte e do Ceará/ maciços do São José do Campestre e Rio Piranhas. São áreas de morfologia e pluviometria privilegiadas (fator orografia acrescendo parcialmente), e domínio freqüente de águas vadosas em quantidades significativas e melhores qualidades que nem sempre têm sido aproveitadas devidamente. Seriam recomendáveis captações mais adequadas (há várias possibilidades, caso a caso) e antecipação de uso e aproveitamento (antes que estas águas se percam por evapotranspiração), tudo isto na dependência de educação e moderada assistência técnica.

Novamente, é necessário destacar a diferença notável entre as condições destes domínios do embasamento do Nordeste semi-árido daqueles semelhantes situados no centro-sul e sudeste brasileiro, onde a presença e a qualificação de águas subterrâneas são muito superiores. Em alguns casos, como nos dos quadriláteros "ferrífero" e "granitífero" do sul do Cráton do São Francisco, em Minas Gerais, constatamos que presença de água subterrânea é tão prolífera que constitui problema sério e onipresente na lavra dos bens minerais (casos de ferro, granito, grafita, por exemplo).

Este exercício de comparação é necessário para, mais uma vez, colocar em evidência a importância do conjunto de variáveis do clima e da fisiografia. Para as mesmas litologias e unidades tectônicas (como visto neste caso e no caso das faixas interiores), muda-se radicalmente o quadro de perspectivas hidrogeológicas nos terrenos cristalinos, quando se tratam das regiões sul e sudeste.

\section{LINEAMENTOS E ZONAS DE CISALHAMENTO - G -}

Na província Borborema, principalmente, há um conjunto importante de zonas de cisalhamentos (shear belts), resultantes do processo de extrusão do final do Proterozóico e início do Fanerozóico, que é responsável, em última análise, pela própria configuração geral geológico-geográfica da província, e da ordenação de todas suas faixas móveis e maciços (Brito Neves et al., 2000).

Em primeiro lugar, a análise da formação das bacias sedimentares paleo-mesozóicas (Jatobá, Mirandiba, Araripe, Médio Jaguaribe, Rio do Peixe etc.) mostra, claramente, que estas bacias, pequenas, médias e grandes, foram condicionadas por movimentos extensionais de magnitudes notáveis (extensão e rejeito) tendo por lugar geométrico preferencial essas zonas de cisalhamento do Proterozóico, devidamente reativadas (vide Cordani et al., 1984).

Em parte, o mesmo pode se dizer para algumas bacias terciárias, como Boa Vista, Cariatá, entre outras (observação pessoal dos autores). No arcabouço destas bacias mesozóicas e cenozóicas do interior, há falhas eoneoproterozóicas (ligadas ou não aos grandes lineamentos), francamente reativadas, atuando consorciadas com falhas mais jovens, meso-cenozóicas, o que tem sido objeto de menção em várias publicações anteriores.

Associado a este primeiro e conspícuo fato geológico, em segundo lugar, é necessário salientar que a procura por estes fenômenos de reativação extensional jamais foi pesquisada devidamente com finalidade de obtenção de águas subterrâneas. Nem estas grandes zonas de cisalhamento nem naquelas tracionais ("T") ou cisalhantes (chamadas Riedel shears, "R", "R”, "P" e "Y", Passchier e Trouw, 


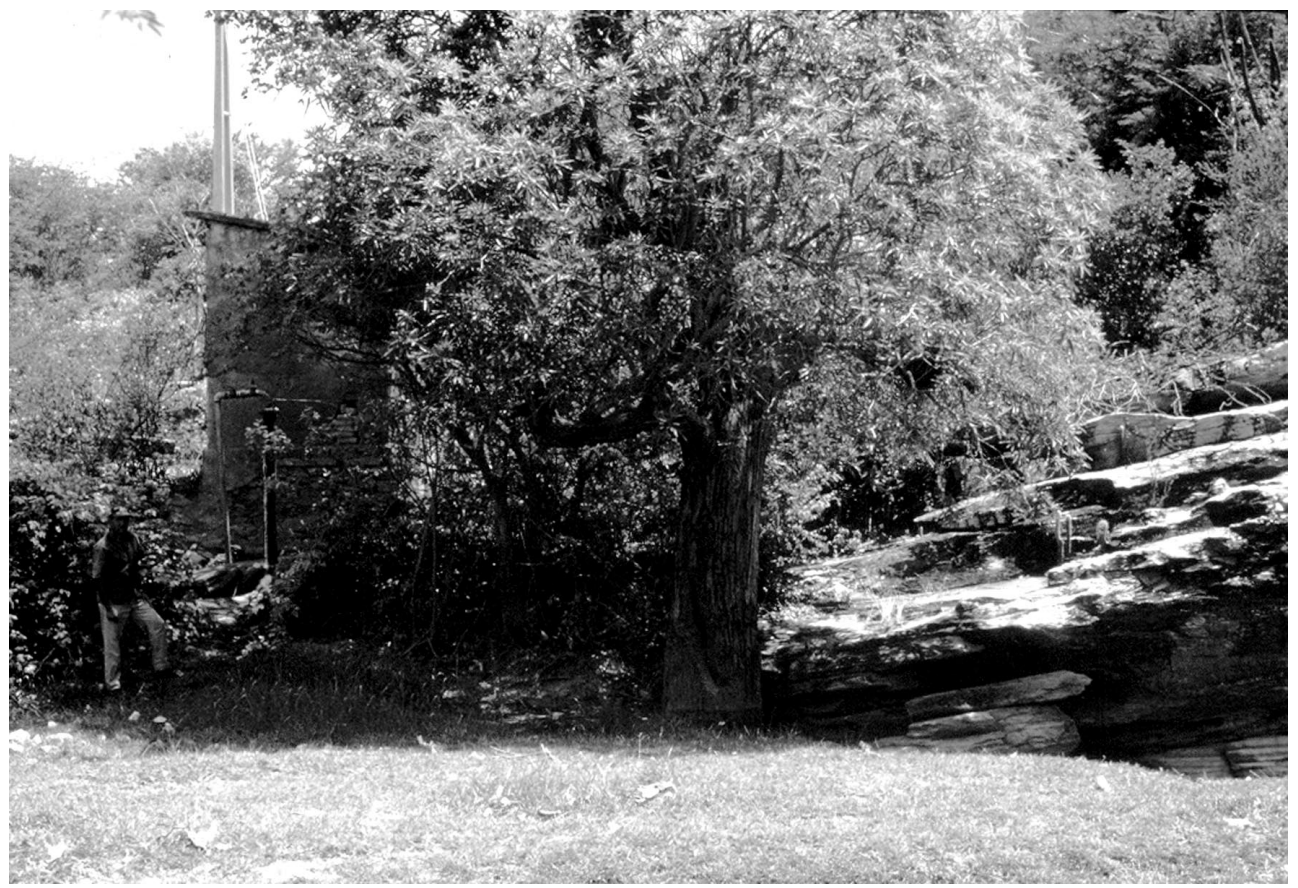

Foto 7. Poço de alto Q/s (acima de $1.000 \mathrm{~L} / \mathrm{h} / \mathrm{m}$ ) nos quartzitos da Formação Equador, faixa Seridó, em Junco - PB. Escolha adequada de litologia para faixas interiores (em serra quartzítica). Este poço chega a abastecer três municípios nas crises de estio.

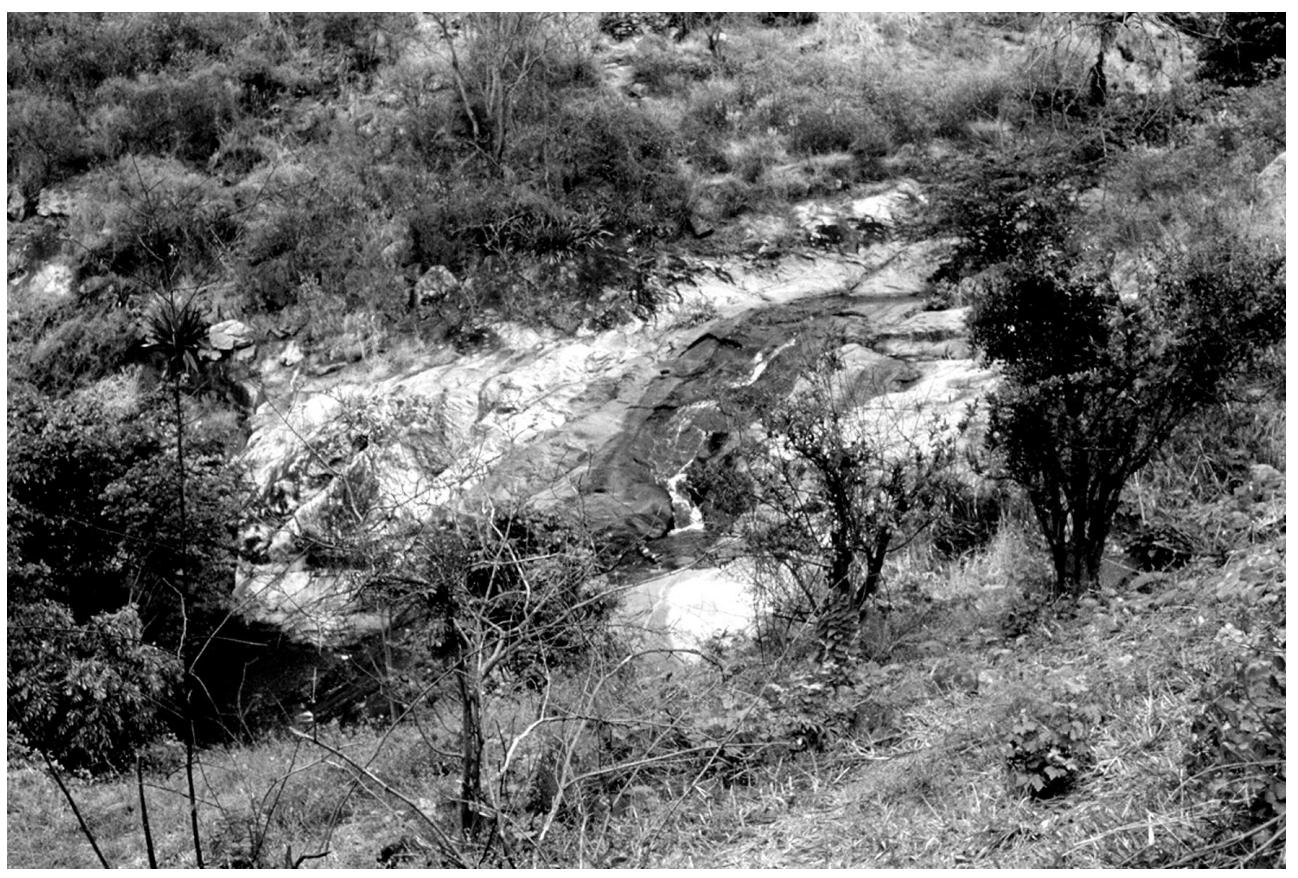

Foto 8. Serra da Baixa Verde: águas vadosas em plena estação das secas, entre Triunfo e Serra Talhada, exsudações disponíveis por longos períodos pós-estação chuvosa. 


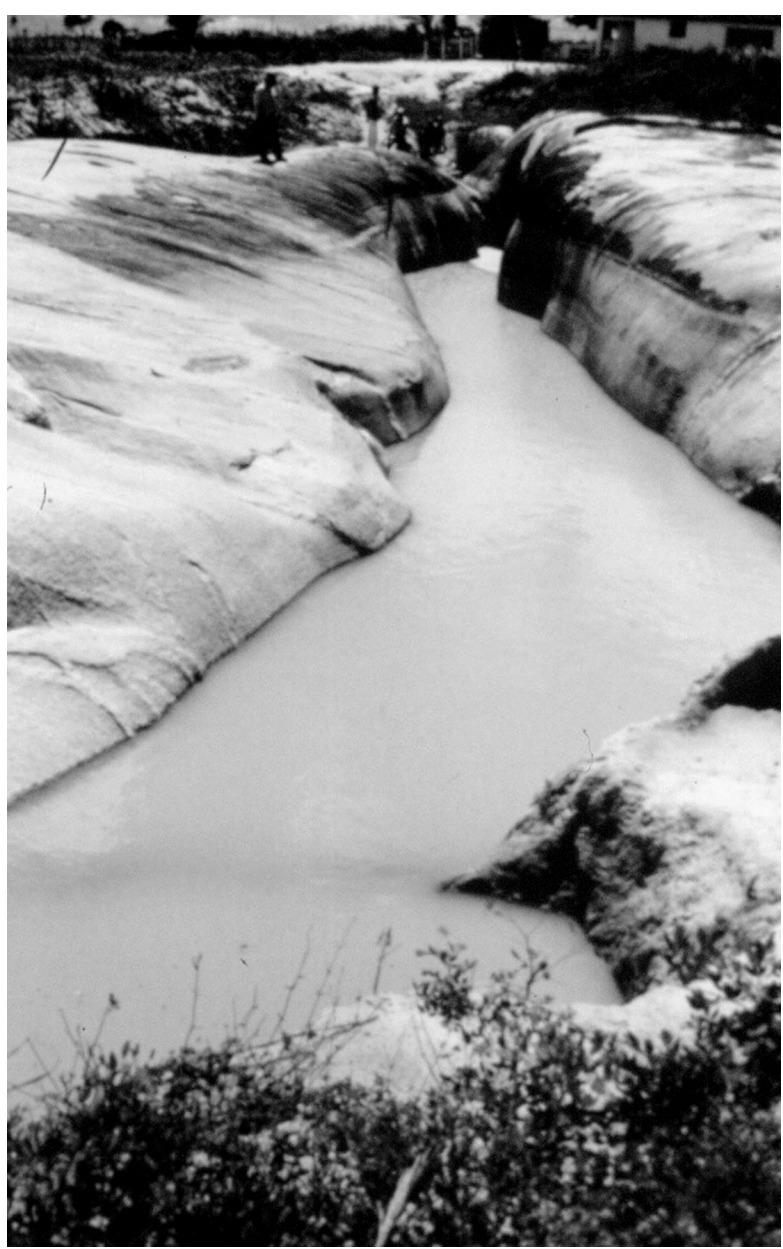

Foto 9. Fratura em posição topográfica elevada ("serra granítica") no complexo de Esperança, em Areial - PB. Situação logo ao final da estação chuvosa. $O$ preenchimento arenoso da zona fendilhada foi retirado artificialmente para melhorar a captação.

1996) consorciadas a esta vigorosa rede de shear belt, mereceram estudos específicos. Esporadicamente se tem reconhecido estes espaços tracionais (primários ou reativados extensionalmente) ocupados por granitóides e bacias romboédricas (ditas transtracionais) cambro-ordovicianas.

Mas é possível que algumas destas disjunções extensionais primárias ("T") e outras zonas de reativação (cisalhantes associadas, reabertas) possam funcionar como zonas aquífferas. Isto, jamais foi objeto de pesquisa sistemática, não obstante alguns resultados (aleatórios e esparsos) de poços locados próximos a esta zona de falhas, com valores elevados de $\mathrm{Q} / \mathrm{s}$, sem causa explicada.

Por seu turno, os estudos neotectônicos têm mostrado uma série de processos (e. g. Moraes Neto e Alkmim, 1999)

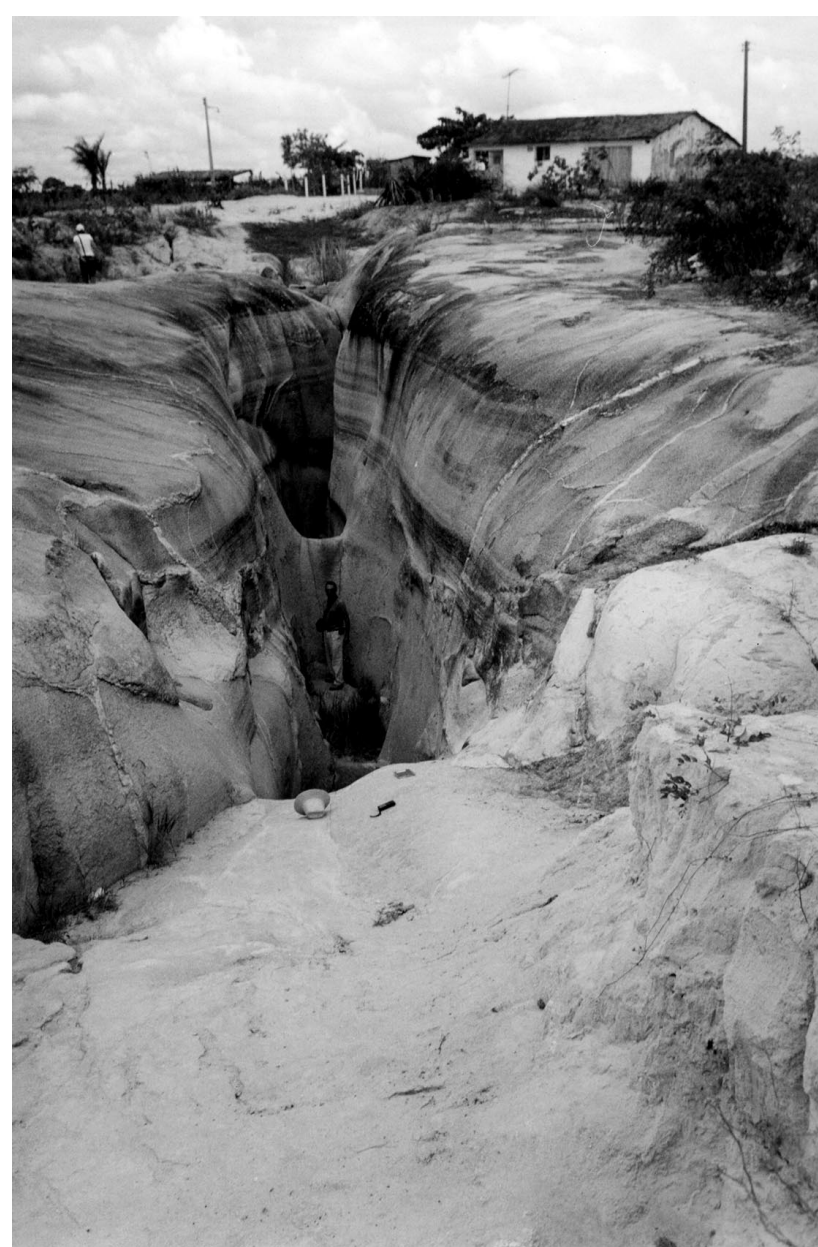

Foto 10. A mesma fratura aberta no Complexo Granítico, na estação das secas (cinco meses após a Foto 9).

de deformação compressional, cisalhante e extensional do Paleógeno Superior para os nossos dias. O quanto estes pulsos tectônicos ativaram os grandes lineamentos (abrindo zonas seladas ou fechando zonas previamente abertas), ainda não é conhecido. Estes domínios dos lineamentos, alguns dos quais chegam a apresentar larguras de uma dezena de quilômetros, são zonas potenciais promissoras de pesquisa e temas candentes para o estudo de águas subterrâneas do sistema cristalino, sendo injustificável a forma com que eles têm sido relegados. Há alguns exemplos de "S" e "L" tectonitos que cortados por zonas de fraturas modernas se comportaram como excelentes sítios de locação. Numa região carente como o Nordeste, esta possibilidade deve ser explorada ao máximo, e doravante motivo de atenção. 
De certa forma, este desconhecimento, lamentado e combatido, contabiliza para o tratamento (G) destes tratos dos terrenos cristalinos. Não há dados estatísticos suficientes para uma análise dos poços situados ao longo destas zonas de cisalhamento. Os poucos que existem (alguns raros de alta capacidade específica) não constituem uma massa crítica suficiente para uma análise. Mesmo porque, estes poços foram locados sem o conhecimento de causa necessário, não são sendo representativos. Mas, os argumentos acima e estes poucos dados pinçados, justificam, ao nosso ver, a separação destas zonas de cisalhamento, como contextos/ tratos especiais que demandam estudos dirigidos.

As zonas de cisalhamento funcionaram nos tempos modernos como colimadoras de chuvas (orografia privilegiada quase sempre ensejada pelos milonitos), e no caso dos estados de Pernambuco e da Paraíba, estas linhas de tectonitos foram ordenadoras, inclusive, da ocupação populacional, onde se encontram grandes centros sócioeconômicos (e. g. Bezerros, Caruaru, Arcoverde etc.). Ao nível de município, há muitas ofertas e muitas possibilidades a serem exploradas e serem estudadas para atendimento de demandas, da melhor forma.

\section{CRITÉRIOS DE LOCAÇÃO}

Desde o clássico trabalho de Siqueira (1963) tem-se utilizado, extensivamente, o critério do "riacho-fenda" para a locação de poços no Sistema Cristalino, qualquer que seja o condicionamento hidrogeológico da área em questão. Nas Fotos 11 e 12, apresentamos exemplos de riachosfendas, longitudinais e transversais (fratura "ac") de um sistema cisalhante, localizado no município de Cuité de Mamanguape - PB.

Durante muito tempo se creditou estes fraturamentos como originados no próprio evento de deformação dúctil das rochas, sem se atinar para o fato de que a estes eventos se sobrepuseram outros esforços tectônicos, principalmente o tectonismo cenozóico, realizado em níveis crustais rasos e de caráter, preponderantemente, distensional, porque associado aos levantamentos continentais, a partir de então desenvolvidos. Albuquerque (1971), de forma mais direta (Moraes Neto e Alkmim, 2001, indiretamente) relacionou a origem destes fraturamentos a um pluri-tectonismo em que os levantamentos epirogênicos teriam desempenhado um papel fundamental na formação de condições aqüíferas no

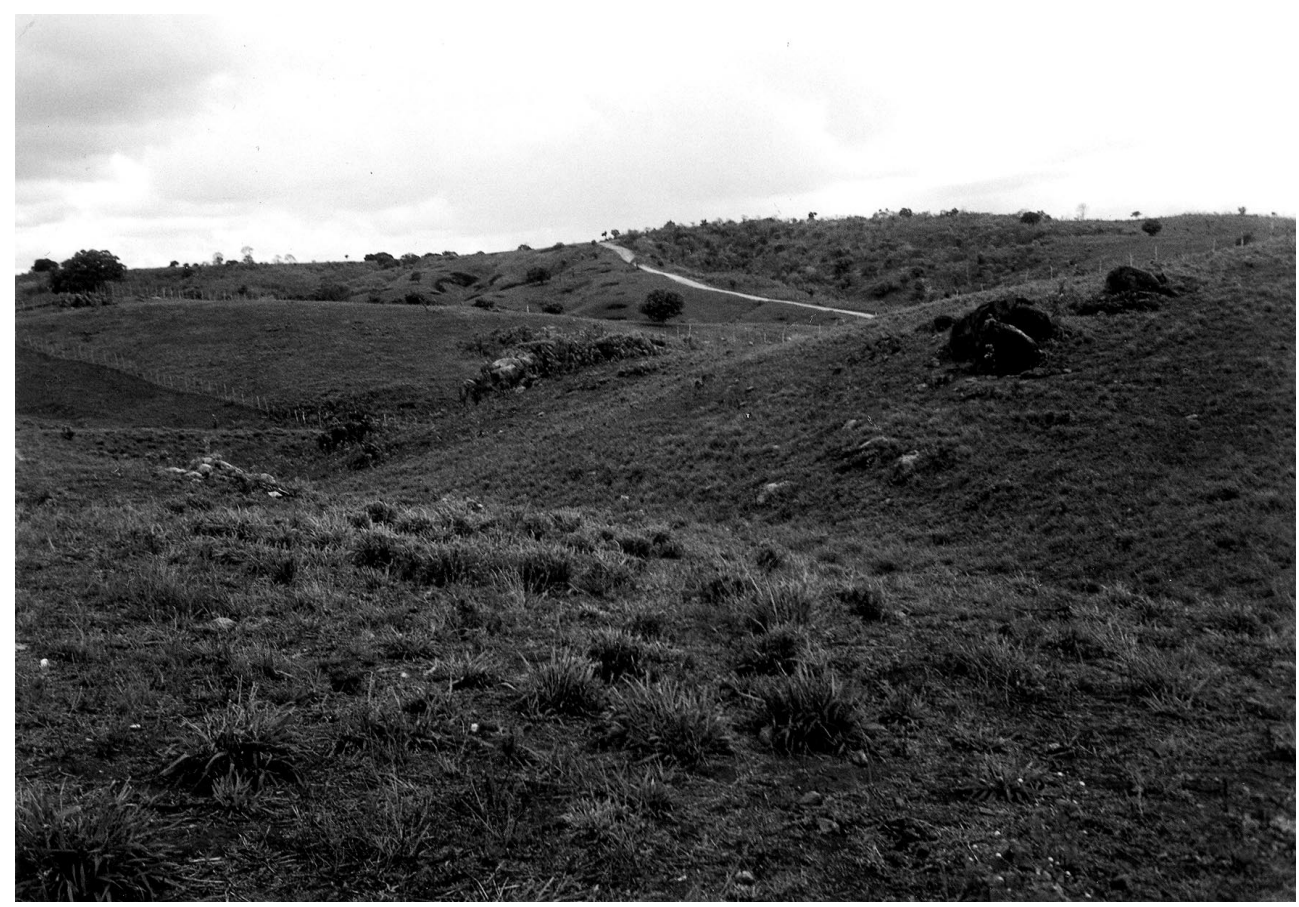

Foto 11. Riacho-fenda longitudinal à zona de cisalhamento Zumbi-Cuité do Mamanguape, leste da Parába. Ao fundo da foto, se pode ver a passagem do riacho para uma linha ortogonal (outro riacho-fenda), mais jovem, aberto, perpendicular à zona de cisalhamento. 


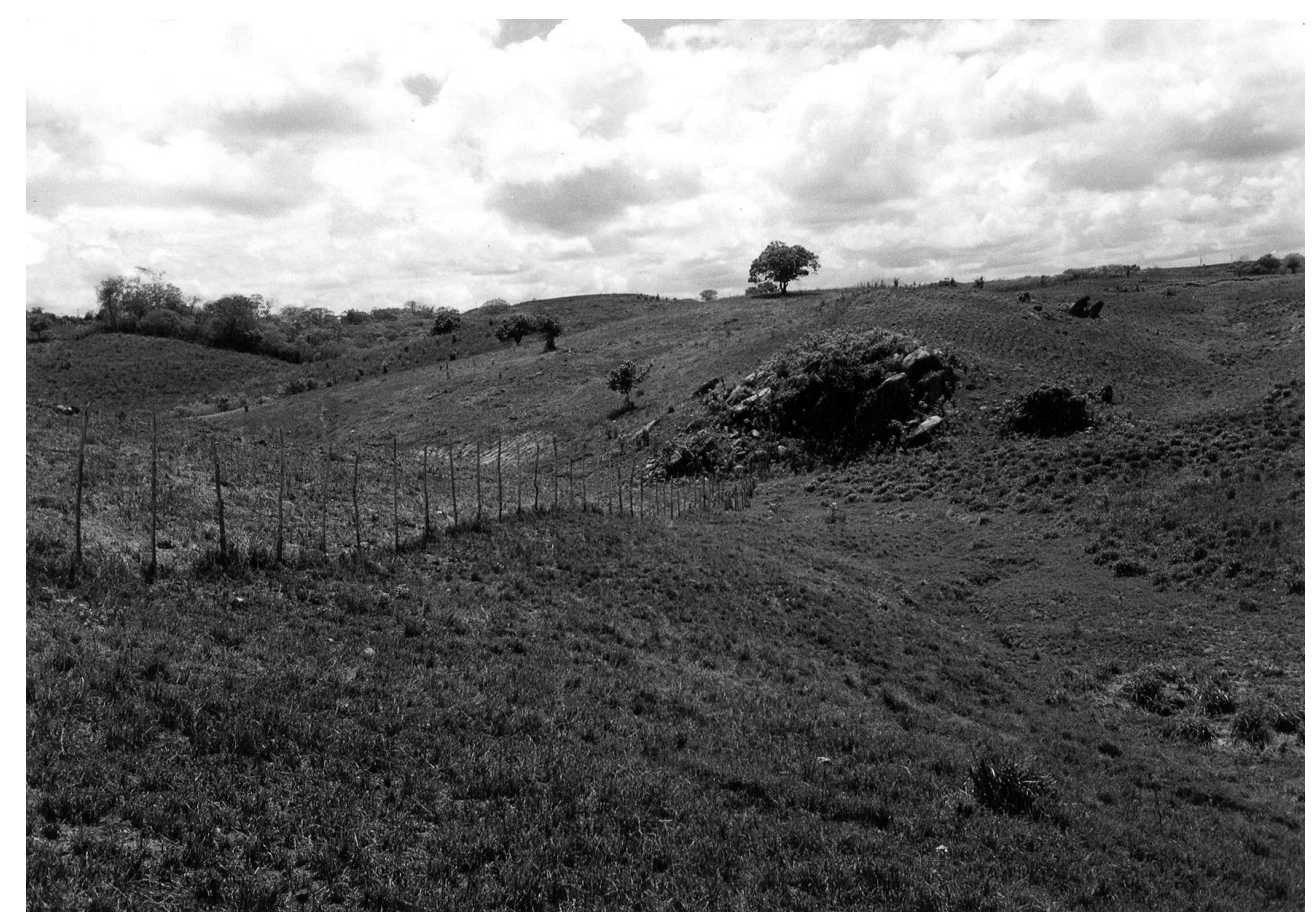

Foto 12. Complemento da foto anterior (Foto 11). Riacho-fenda (que capturou o curso d'água) perpendicular à zona de cisalhamento Zumbi-Cuité do Mamanguape. Estes tipos perpendiculares aos trends principais de foliação são os preferidos para locação de poços na Borborema.

domínio do embasamento cristalino e na instalação de rede hidrográfica estabelecida a partir de então.

Ao longo deste trabalho foi demonstrado que, apesar da validade do critério riacho-fenda, principalmente no contexto das Faixas Interiores, do Embasamento do Cráton e dos Maciços, outros condicionamentos aqüíferos ocorrem no Sistema Cristalino. Assim sendo, juntas, contatos, discordâncias, zonas ou lineamentos de falhas e, mesmo, rochas de porosidade intersticial e cárstica (quartzitos e calcários cristalinos, respectivamente), entre outras, podem originar unidades aqüíferas distintas com conseqüentes critérios de locação específicos.

Novas metodologias de locação de poços têm sido propostas e desenvolvidas (como o da calha elúvio-coluvionar, Silva et al., 2000), e outros, com apoio de métodos geofísicos (aerogeofísica e geofísica terrestre, CPRM, 2002), mas a evolução destas técnicas é muito pequena ainda, tem grande espaço pela frente, considerando ou não os sete tipos de tratos aqui postulados.

Ao identificar, com o apoio da caracterização geotectônica, os sete condicionamentos hidrogeológicos integrantes do sistema Cristalino, a intenção dos autores é evidenciar novos caminhos de pesquisa aplicada e de critérios de locação de poços.

\section{AGRADECIMENTOS}

Os autores desejam expressar o agradecimento a dois revisores anônimos, que contribuíram decisiva e construtivamente para elaboração do texto final, e também fazem referência especial aos geólogos da SUDENE, Divisão de Hidrogeologia e CONESP, que ao longo da convivência de muitos anos nos passaram muitos ensinamentos, contribuíram de forma notável, com discussões, opiniões e dados para o nosso aprendizado e para os conhecimentos aqui sintetizados.

\section{REFERÊNCIAS BIBLIOGRÁFICAS}

ALBUQUERQUE, J. P. T. Os recursos de água subterrânea do trópico semi-árido do Estado da Paraíba. 1984. 183 f. Dissertação (Mestrado) - Departamento de Engenharia de Minas, Universidade Federal da Paraíba, Campina Grande.

ALBUQUERQUE, J. P. T. Contribuição ao conhecimento do sistema cristalino no Estado da Paraíba como meio aqǘfero. In: CONGRESSO BRASILEIRO DE ÁGUAS SUBTERRÂANEAS, 3., 1984. Fortaleza. Anais... Fortaleza:ABAS, 1984. p.489-506.

ALBUQUERQUE, J. P. T. Contribution to the understanding 
of crystalline systems as aquifers - the experience of the State of Paraíba, Northeast Brazil. In: INTERNATIONAL CONFERENCEONGROUNDWATER INFRACTURED ROCKS, 2003. Prague,. Proceedings... Prague: IAH/UNESCO, 2003. p. 21-22.

ALMEIDA, F. F. M.; BRITO NEVES, B. B.; CARNEIRO, C. D. R. The origin and evolution of the South American Platform. Earth Science Reviews, Amsterdam, v. 50, p.77-112, 2000.

ATECEL/UFPB-SEPLAN/GOVERNO DAPARAÍBA. Plano Estadual e Sistema de Gerenciamento de Recursos Hídricos. Anexo 6 - disponibilidade hídrica subterrânea. Plano de governo. Governo do Estado da Paraíba. Secretaria de Recursos Hídricos. João Pessoa, 1994. (circulação restrita)

ATKINSON, L. C.; GALE, J. E.; DUDGEON, C. R. New insight into the step-drawdown test in fractured rocks. Applied Hydrogeology, v. 2, p. 9-18, 1994.

BRITO NEVES, B. B. Inventário hidrogeológico básico do Nordeste - folha 24 - Aracajú - SO. Série Hidrogeologia. Recife: SUDENE. Divisão de Hidrogeologia, v. 26, 1972.

BRITO NEVES, B. B.; ALBUQUERQUE, J. P. T. Tectonics and groundwater research: Proterozoic Borborema Province, a semiarid region of Northeast Brazil. In: INTERNATIONAL SYMPOSIUM ON ENGINEERING GEOLOGYAND THE ENVIRONMENT, 1997. Athens. Proceedings... Rotterdam; Brookfield: A . A . Bakelma, 1997. p. 1181-1186.

BRITO NEVES, B. B.; SANTOS, E. J.; VAN SCHMUS, W. R.. The tectonic History of the Borborema province. In: CORDANI, U. G.; MILANI, E. J.; THOMAZ FILHO, A.; CAMPOS, D.A. (Ed.). INTERNATIONALGEOLOGICAL CONGRESS, 31., 2000. Rio de Janeiro. Tectonic evolution of South América... Rio de Janeiro, 2000. p. 151-182.

CORDANI, U. G.; BRITO NEVES, B. B.; FUCK, R. A.; PORTO, R.; THOMAZ FILHO, A.; BEZERRADA CUNHA, F. M. Estudo preliminar de integração do Pré-Cambriano com os eventos tectônicos das Bacias Sedimentares Brasileiras. Ciência-Técnica-Petróleo, Rio de Janeiro, v. 15, p.1-70, 1984.

COSTA, W. D. Análise dos fatores que atuam no aqüífero fissural - área piloto dos estados da Paraíba e do Rio Grande do Norte. 1986. 225 f. Tese (Doutorado) - Instituto de Geociências, Universidade de São Paulo, São Paulo.

COSTA, W. D. Aspectos macro-estruturais que influem na hidrogeologia de rochas cristalinas fraturadas. São Paulo: Instituto de Geociências. Universidade de São Paulo. 73 p. (Monografia apresentada em seminário de pós-graduação, circulação restrita.)

COSTA, W. C. Fenomenologia dos processos envolvidos com a quantificação e qualificação de água subterrâ- nea em rochas cristalinas. São Paulo: Instituto de Geociências. Universidade de São Paulo, 1998. 32 p. (Monografia apresentada em seminário de pós-graduação, circulação restrita.)

CPRM - Serviço Geológico do Brasil. RELATÓRIO ANUAL 2002. Brasília: Ministério de Minas e Energia, 2002. (Circulação restrita)

CRUZ, W. B.; MELO, F.A. C. F. Estudo geoquímico preliminar das águas subterrâneas do Nordeste do Brasil., Recife: Brasil/SUDENE, 1968. 147p. (Série Hidrogeologia, 19).

DRN/BRASIL/SUDENE. Atlas de recursos naturais do Nordeste. Recife: Ministério do Interior Superintendência de Desenvolvimento do Nordeste. Departamento de Recursos Naturais, 1974. 8 mapas.

GUERRA, A. M. Processos de carstificação e hidrogeologia do Grupo Bambuí na região de Irecê-Bahia. 1968. 132 f. Tese (Doutorado) - Instituto de Geociências, Universidade de São Paulo, São Paulo.

HOBBS, B. E.; MEANS, W. D.; WILLIAMS, P. F. An outline of structural geology. New York: J. Wiley \& Sons, 1976. $571 \mathrm{p}$.

LANDIM, J. M. D.; MISI, A. (Ed.). O Cráton do São Francisco. Salvador: SBG-Núcleo Bahia e Sergipe/SGM/ CNPq, 1993.203 p.

MANDELBROT, B. B. The fractal geometry of nature. New York: Freeman, 1983. $468 \mathrm{p}$.

MANOEL FILHO, J. Modelo de dimensão fractal para avaliação de parâmetros hidráulicos em meio fissural. 1996. 197 p. Tese (Doutorado) - Instituto de Geociências, Universidade de São Paulo, São Paulo.

MORAES NETO, J. M.; ALKMIM, F. F. A deformação das coberturas terciárias do Planalto da Borborema (PB-RN) e seu significado tectônico. Revista Brasileira de Geociências, São Paulo, v. 31, p. 95-106, 2001.

PASSCHIER, C. W.; TROUW, R. A. J. Microtectonics. Berlin: Springer-Verlag, 1996. 289 p.

PINTO, A. S.; SANTOS, P. R. P.; ALMEIDA, J. A. B.; MATOS, I . V. Critérios de locação e aspectos práticos da perfuração em rochas calcárias da região central do Estado da Bahia. In: CONGRESSO BRASILEIRO DE ÁGUAS SUBTERRÂNEAS, 2., Salvador, 1982. Anais... Salvador: ABAS, 1982. p. 447-461.

REBOUÇAS, A. C. Groundwater in Brazil. Episodes, Ottawa, v. 11, p. 209-214, 1998

REBOUÇAS, A. C. As águas subterrâneas do Nordeste do Brasil. Estimativas Preliminares. Série Hidrogeologia, Recife: Brasil/SUDENE, n. 6, 1966.

REBOUÇAS, A. C.; BRAGA, B.; TUNDISI, J. G. (Org.). Águas doces no Brasil. 2. ed. São Paulo: Escrituras, 2002. 703 p.

RIEDEL, W. Zur Mechanik geologischer Brucherscheinungen. Zentralblatt für Geologie und Palaontologie, Stuttgart, p. 354-368, 1929. 
SANTOS, P. R. P.; DURÃES, A. M. M. Hidrogeologia do Grupo Chapada Diamantina e do Grupo Paraguassú. In: CONGRESSO BRASILEIRO DE ÁGUAS SUBTERRÂNEAS, 4., 1986. Brasília. Anais... Brasília: ABAS, 1986. p. 106-119.

SILVA, A. B. Análise morfoestrutural, hidrogeológica e hidroquímica do aquífero cárstico de Jaíba, norte de Minas Gerais. 1984. 190 f. Tese (Doutorado) - Instituto de Geociências, Universidade de São Paulo, São Paulo.

SILVA, A. B. Contribuição da geologia estrutural na explotação de águas subterrâneas do Grupo Bambuí na região norte do Estado de Minas Gerais. In: CONGRESSO BRASILEIRO DE ÁGUAS SUBTERRÂNEAS, 4., 1986. Brasília. Anais. .. Brasília: ABAS, 1986. p. 251-262.

SILVA, C. C. N.; SILVA, J.A.; MEDEIROS, W. E.; JARDIM DESÁ, E. F.; STEENSMAN, G.; KELLER, R. Riacho-Fenda versus calha elúvio-coluvionar: um teste com o método EM - 34 sobre estruturas de acumulação de água subterrânea em terrenos cristalinos. In: SIMPÓSIO DSE GEOLOGIADONORDESTE, 18., 2000. Recife. Resumos... Recife: SBG-NO, 2000.p. 181.

SILVA, J. A.; SILVA, C. C. N.; MEDEIROS, W. E.; JARDIM DE SÁ, E. F. Critérios para locação de poços para águas subterrâneas em terrenos cristalinos com base nos modelos riacho-fenda e calha elúvio-coluvionar. In: SIMPÓSIO DE GEOLOGIA DO NORDESTE, 18., 2000. Recife. Resumos... Recife: SBG-NO, 2000. p. 183.

SIQUEIRA, L. Contribuição da Geologia à pesquisa de água subterrânea no cristalino. Recife: Grupo de Trabalhos em Águas Subterrânea-GTAS. Departamento de Recursos Naturais. DRN/SUDENE. 53 p. (Monografia, circulação restrita.)

SOUZA, M. F. Água subterrânea no semi-árido nordestino e seu engajamento no desenvolvimento regional. In: CONGRESSO BRASILEIRO DE ÁGUAS SUBTERRÂNEAS, 4., 1986. Brasília. Anais... Brasília: ABAS, 1986. p. 146-158. 